\title{
WestVirginiaUniversity
}

THE RESEARCH REPOSITORY @ WVU

Graduate Theses, Dissertations, and Problem Reports

2013

\section{The Rationale for Ridiculous}

\author{
Erica E. Passage \\ West Virginia University
}

Follow this and additional works at: https://researchrepository.wvu.edu/etd

\section{Recommended Citation}

Passage, Erica E., "The Rationale for Ridiculous" (2013). Graduate Theses, Dissertations, and Problem Reports. 595.

https://researchrepository.wvu.edu/etd/595

This Thesis is protected by copyright and/or related rights. It has been brought to you by the The Research Repository @ WVU with permission from the rights-holder(s). You are free to use this Thesis in any way that is permitted by the copyright and related rights legislation that applies to your use. For other uses you must obtain permission from the rights-holder(s) directly, unless additional rights are indicated by a Creative Commons license in the record and/ or on the work itself. This Thesis has been accepted for inclusion in WVU Graduate Theses, Dissertations, and Problem Reports collection by an authorized administrator of The Research Repository @ WVU. For more information, please contact researchrepository@mail.wvu.edu. 
The Rationale for Ridiculous

\author{
Erica E. Passage
}

Thesis submitted to the

College of Creative Arts

At West Virginia University

in partial fulfillment of the requirements

for the degree of

Master of Fine Arts

in

Ceramics

Shoji Satake, M.F.A., Committee Chair

Robert Moore, M.F.A.

Michael Sherwin, M.F.A.

Naijun Zhang, M.F.A.

Jennifer Allen, M.F.A.

School of Art and Design

\author{
Morgantown, West Virginia \\ 2013
}

Keywords: Ceramics, Pottery, Clay, Art, Fine Art, Drawing, Sketchbook, Process 


\author{
Abstract \\ The Rationale for Ridiculous \\ by Erica E. Passage
}

This thesis is a description and analysis of the ceramic work of Erica E. Passage. This thesis includes a description and images of the work for the thesis exhibition The Rationale for Ridiculous as well as a discussion pertaining to the conceptual, technical and formal content of the work. 


\section{Acknowledgements}

I want to take this time to thank my graduate committee and the entire faculty of the West Virginia University Creative Arts Department for providing me with the necessary resources and encouragement to explore and find my creative voice. A very special thanks goes out to Shoji Satake, Robert "Boomer" Moore and Jennifer Allen. I could have never imagined the amount of knowledge that you have given to me and I could not be happier with the creative community I found myself in. I would also like to thank my fellow graduate students and studio-mates for all of the inspiration you gave me concerning this body of work 
Table of Contents

Abstract......................................ii

Acknowledgements...........................iii

Table of Contents............................. v-vi

List of Figures...................................

Introduction...................................

Chapter 1: Process................................. 3

Chapter 2: Influences.................................
A. Form.
.7
B. Surface........................... 8
C. Ceramic Influences.................10

Chapter 3: The Rationale for Ridiculous....13

Chapter 4: Conclusion........................16

Figures........................................... 17

Bibliography..................................... 39

Curriculum Vitae................................41 


\section{List of Figures:}

Page 17. Figure 1: This Will Get Me Through My Day (Close-up of Mug Installation)

Page 18-20. Figure 2: Sassy Snack Plate

Page 21. Figures 3-11: Sketchbook Images (Fall 2010- Spring 2013)

Page 22. Figure 12: Jeffrey Brown

Page 23. Figure 13: Daniel Clowes

Page 23. Figure 14: Craig Thompson

Page 24. Figure 15: Jay Ryan

Page 25. Figure 16: Matte Stephens

Page 26. Figure 17: Oliver Jeffers

Page 27. Figure 18: Mayan Codex Vessel

Page 28. Figure 19: Maiolica Bowls

Page 29. Figure 20: Ming Dynasty Jar

Page 30. Figure 21: Maiolica Pharmacy Jar

Page 31. Figure 22: Linda Christianson

Page 32. Figure 23-24: Simon Levin

Page 33. Figure 25-26: Brian R. Jones

Page 34. Figure 27-28: Ayumi Horie

Page 35. Figure 29: This Will Get Me Though My Day

Page 36. Figure 30: Morning Maker with Informational Receiving Antenna 
Page 36. Figure 31: They Say Practice Make Perfect

Page 37. Figure 32: Collective Joy for the Masses

Page 38. Figure 33: Sometimes the Answers are Hard to Find

Page 38. Figure 34: A Little Scrubbing Might Solve the Problem 
Introduction

I enjoy making pots that can rescue one from the monotony of everyday activity. I often imagine the situation my pots will find themselves when they become a part of someone else's life. I am intrigued by the possible contents my pots will hold, the dinner parties they will enhance and the hands they will pass through once finding a home. The thrown forms I create beg to be engaged with an array of images and vibrant color. Animals, text and simple layering techniques are three features that I incorporate onto the surface of my pottery. Through my pots I intend to physically and psychologically capture and draw attention to fleeting moments.

I intentionally make forms that undulate in order to reference moments that pass through one's life. Fleeting moments are captured in a person's memory and instilled in much like the movements my hands and tools make with the forms I create. Covered by a white opaque slip, the facade conceals the underlying clay body and acts to hide the clay body from the decoration I place on its surface.

Using line, language, image and pattern I create a balance between a narrative and form. The animals are metaphors, for human conditions that embrace the humor and satire that occur around me daily. The characters that are drawn on the surface of my work are benign and observant. They consist of a cat and blue rabbits. Clementine, the cat, is a representation of my childhood pet. Feral, angry, and bitter my version of Clementine plays the role of the antagonist that questions the existence and decisions of the blue rabbits. They look at the viewer and glance at each other with blank stares as if they are unsure about their true calling and meaning in the world. The text in the banners are glimpses of the personal monologue that plays through my head. I choose to place the text in banners as a way to celebrate the negative and sometimes self-destructive thoughts that I keep trapped and confined in my own body. When the objects are amassed the language becomes overwhelming 
chatter. The banners and animal characters are encircled in a ray of printed patterns that reference the static noise and information that drone through daily life occurrences (Fig. 1).

\section{Chapter 1: Process}

\section{A. Pottery}

The potter's wheel gives the maker the opportunity to push, pull and distort the round perfect clay balls into a unique piece that represents the hand of the maker. ${ }^{1}$ My pots capture the moment of creation and my movements on the potter's wheel when I am making objects ${ }^{2}$. One can create pots quickly when using the potter's wheel. After the clay objects dry and are fired in a kiln, during the initial bisque firing, the movements that I make are forever solidified and fixed within the object. Clay, when it is molded, distorted, pushed and pulled retains its shape and the actions of the maker. As a maker capturing movement and gesture are more important to me than crafting the symmetrical object. Paul Mathieu, in his essay The Art of the Future: 14 Essays on Ceramics states, "This is one of the reasons why ceramics is such a difficult art form and good pottery one of the most difficult thing to do. It doesn't tolerate any indecision, insecurity, doubt or change of mind but needs to be done with assurance, sureness, confidence and a deep, absorbed and instinctive knowledge that takes years to acquire and is the reserved privilege of very few." ${ }^{3}$ Utilitarian pottery not only needs to function as a piece of art in one's home but it also must perform its role as a functional object that will serve the needs of nourishment in

${ }^{1}$ Howard. "A Theory of Craft: Function and Aesthetic Expression." (Chapel Hill: University of North Carolina Press, 2007) 109.

2 Howard. "A Theory of Craft: Function and Aesthetic Expression." (Chapel Hill: University of North Carolina Press, 2007)110.

${ }^{3}$ Mathieu. "The Art of the Future: 14 Essays of Ceramics." www.paulmathieu.ca/ 
the highest manner. ${ }^{4}$ The process of ceramics can be humbling even after testing, planning and making countless forms from clay.

I choose to make my pots out of a terra-cotta clay body. Terra-cotta means burnt-earth and is associated with roofing tiles, drainpipes and garden planters. Terra cotta was and continues to be the most abundant type of clay that was reserved for pots that were used on a daily basis. It is secondary clay that can be found naturally in the earth. Because of its inexpensive cost and lower firing temperatures terra-cotta was the clay associated with peasant ware. Furthermore, terra cotta remains porous after its initial bisque firing. To make the objects water tight one must glaze the pieces or the bisque fired clay will absorb any liquids it comes in contact with.

The pots I make are then covered with an opaque white slip. The slip acts as a blanket. ${ }^{5}$ It protects the clay much like a fresh covering of snow in the winter protects and covers the landscape. Furthermore, the white slip is a smooth white surface and creates a canvas for drawings and printed textures I place on the surface of my pots. The white surface acts like a sheet of blank paper that I activate though drawing.

\section{Surface}

The animals that I draw on the surface of my pots consist of a rabbit and a cat. I choose to use these two animals because of a personal connection I have to them. The image of the rabbit comes directly from my childhood and the memory I have of my stuffed companion. The yellow cat refers to my own pet cat, Clementine. The rabbit represents myself as an adult and the cat acts as a metaphor for the relationship struggles of loss that enter one's life as an adult. The distorted form of the rabbit and cat come from my desire to use ideas and theories of cute in my work. Harris states in "Cute, Quaint, hungry and

\footnotetext{
${ }^{4}$ Rawson. "Ceramics"

${ }^{5}$ Wolk. "Reading Comics: How Graphic Novels Work and What They Mean." (Cambridge: Da Capo Press, 2007) 208-209.
} 
Romantic," In order for something to be considered cute it must have child-like characteristics. ${ }^{6}$ For example, when one renders something "cute," it is often associated with feeling of helplessness and a need for protection. Formally, the characteristics of something that is considered cute will often have an oversized head, large forehead, eyes and ears that are proportionally low on the face and far apart, a rounded nose and a soft round body. ${ }^{7}$ I employ the use of cute as a way to distill intended cruelty and truthful reality pertaining to the animals that are on the surface of my pot. It is my goal as a maker to try and capture the satire of their existence. The characters I draw on my pots have round over stuffed bodies, elongated appendages, as if they were stretched from over use, large oval heads and small eyes placed far apart on the head.

The animals on my pots use cute as an attempt to capture the attention of the viewer and stimulate a sense of pity towards the image. The animals I place on the surface of my work are not cheerful and happy. They are trapped, immobile, static and unchanging much like a child's stuff toy. "The process of conveying cuteness to the viewer disempowers the object, forcing them into ridiculous situations and making them appear more ignorant and vulnerable than they really are." 8

Clementine and the blue rabbit share the same surface with text filled banners (Fig. 11). The text that I choose to place in the banners comes from my incessant monologue. Many times the text that appears on the surface of my work consists of questions pertaining to my current situation at a specific time and place. Other times, the text is brash, harsh, demeaning and is pointed directly toward a certain person. Such as "you sound stupid," "you are a big joke" and "why is this important." My thoughts are the inspiration for the text

${ }^{6}$ Harris. "Cute, Quaint, Hungry and Romantic, The Aesthetics of Consumerism." (Da Capo Press, 2000), 1-21.

7 Wolk. "Reading Comics: How Graphic Novels Work and What They Mean." (Cambridge: Da Capo Press, 2007) 203.

${ }^{8}$ Harris. "Cute, Quaint, Hungry and Romantic, The Aesthetics of Consumerism." (Da Capo Press, 2000), 6. 
on my pots but the words are never verbally spoken. The cute animals combined with the text start to form a dialogue of their own. One begins to question if the animals are thinking, saying or celebrating the text that surrounds. The animals are used in conjunction with the text as a way to bring me comfort and as a way to make the questions and statements ambiguous as a phrase that the viewer create their own associations.

Traditionally, a banner was a piece of material bearing a symbol, logo, slogan or other message. Many times banners were used to give official proclamations and show rallying points in battle. Most often today, banners are used for announcements. ${ }^{9}$ The banner and celebration ribbons can traditionally be seen hanging from ceilings at birthday parties and wrapped diagonally around the bodies of beauty pageant contestants. In my work, banners act as both an element of design and a form of celebration. Banners draw attention to a situation and hold text that is pertinent to a certain place, time or situation. Much like the traditional use of banners, the banners in my work celebrate my thoughts made permanent on the surface of the pots. By employing a long flowing banner as a design element that envelops my pottery, the eye of the viewer is directed around the ceramic object and the viewer must turn and rotate the object to fully read the banner.

\section{B. Drawing}

Drawing and mark making have always been a needed and necessary step in my art making. As a child and now as an adult, I carry a sketchbook. My mother first introduced me to keeping a sketchbook. It was necessary for her sanity on long car rides and hours spent in church. My sketchbook (thoughts being represented on paper) still anchor me to my chair and lock my mouth. I am free to say whatever I want in my sketchbooks. I create fantastical lands that remove me, making my imagination swirl with amazing capacity. The choice of

9. Crampton. "The World of Flags." (Rand McNally, 1994) 
sketchbook have evolved as with my art making from a composition book purchased at the grocery store to black leather bound books and now to handmade sketchbooks made from neglected library books (covers) and found paper (inside text block) (Fig 3-11). There are times my sketchbook becomes a source of refuge and security. I look to them not only for inspiration but also as an immediate source of creativity. The freedom I find when making quick gestural sketches is addictive as the drawings in my sketchbook become a daily source of my inner detritus. They capture daily ephemeral moments as a type of scientific field journal. "For scientists of all kinds, keeping a field journal enhances learning by providing a platform for the integration of experimental data. The sketchbook is a place where the details of research and experiments can be recorded, and hypotheses considered. By making connections on the pages of a sketchbook, scientists link observation and memory." ${ }^{10}$ Much like a scientist's journal, my sketchbook becomes a place where my experimental data is stored. Images, text and banners from my sketchbook are then translated onto my pots. Not only do my sketchbooks contain sketches of ephemeral subjects, daily moments and ideas they also contain recipes for glazes, class notes and charts pertaining to kiln firings. My sketchbook is a field guide for my ceramic process.

\section{Chapter 2: Influences}

Throughout my time at WVU my ceramics professor Shoji Satake engrained in me that sometimes the best influences one can bring into their work is not ceramic and the more obscure one's influences become the more exciting his or her work will become. With his statement, I finally found the freedom to explore and push my influences in new directions. I began looking at things that I wanted to see and translate into my ceramic work. I no longer felt as if my influences were not serious or academic enough. I began looking at

\footnotetext{
10 Sands and Topnika. "Sketching as a Science Tool."
} 
analog music recorded on vinyl, graphic novels, and indie rock posters as sources of influence in the objects that I make. However, I still look at potters for inspiration and technical answers when making pottery but my surface decoration and forms reference the music that plays though my headphones on a daily basis and the surface I place on my pots references the strange visual world music creates, the layering and narrative that appears in graphic novels and the design and style indie rock music posters encompass.

\section{A. Influences on Form}

I make pots that people have a daily association with: mugs, plates, bowls and tumblers. Making these forms are important because of their use on a daily basis. I want my pots to be used daily and the text and imagery on their surface to be reminders of the questions that pass though one's life.

When I am not in the studio, when I am home, I listen to music that plays from my collection of vinyl records. I have always been transfixed with vinyl records and my collection has grown from just a few LPs that I found at a local garage sale, to hundreds of records that break my wallet and back every time I change locations. I am always amazed at how heavy and cumbersome boxes of vinyl records become but as individual objects they are beautiful. The white static noise produced by a vinyl record is different with each and every one. ${ }^{11}$ It is an unintentional individualized musical fingerprint that only appears after time and use. The way a used and loved record moves under the needle with an up and down wavy motion on the turntable is completely hypnotic. The inconsistencies, or white noise, that appear only after human use give the object a life and a presence that is particular for only that record. The music becomes more what the artist intended because the album starts to have its own voice. Furthermore, vinyl music is analog. The recorded sound wave produced by

${ }^{11}$ Boilen and Hilton, National Public Radio. "Flaming Lips' Wayne Coyne Guest DJ." NPR All Songs Considered. April 9, 2013. www.npr.org/blogs/allsongs/. April 10, 2013 
analog music is fluid, continuous and undulating this is much different from the digital sound wave. Digital music has a sound wave that is step-like because when recorded the sound wave is converted to a series of numbers.

Musical composer John Cage stated, "When I hear what we call music, it seems to me that someone is talking and talking about his feelings and or about ideas of relationship. But when I hear traffic, the sound of traffic I don't have the feeling anyone is talking. I have the feeling that sound is talking. And I love the activity of sound. I don't need sound to talk to me."12 The static white noise that appears on an analog recording is the activity of sound. It shows that one must actively listen to music on vinyl. The record must be flipped and the needle must be lifted to go back to one's favorite song. There is no shuffle and no repeat. A person is forced to listen to the music the way the artist intended.

It was not until I saw the beauty in an imperfect well-loved vinyl record that my pots started moving and undulating in an intentional captured manner. When making pots, I am asking the user to interact with something that I create. Similar to the way the listener of a vinyl record must interact with the turntable and vinyl record over short periods of time I am asking the viewers of my pots to interact with them and give them a life that I intend for them to have. I want my pots to be used on a daily basis by people. Over time, the objects I create will have an unintentional history of their own through the chips, cracks and stains that appear on their surface. This will become the ceramic white noise or the unintentional marks the artists did not intend but the user created.

\section{B. Surface Influences}

Comic books and graphic novels are also a source of inspiration for the works that I create. There are many times when the creator of a comic book is

\footnotetext{
12 Larson. "Where the Heart Beats: John Cage, Zen Buddhism and the Inner Life of Artists." (New York: Penguin Press).
} 
trying to establish a sentimental memoir with the reader. ${ }^{13}$ Comic book artists such as Jeffery Brown (Fig. 12), Daniel Clowes (Fig. 13) and Craig Thompson (Fig. 14) are three graphic novelists that I look to on a regular basis for compositional design elements that I pull into my work. Each of these artists have a unique and individualized drawing style. Jeffrey Brown chronicles the daily life of his gray cat. ${ }^{14}$ He uses thick purposeful lines in his drawings that reduce his images to that of the style of a coloring book. On the other hand, Craig Thompson and Daniel Clowes use much more painterly and gestural drawing styles. The drawing style of these two artists creates a movement that leads the viewer through the pages of their graphic novels. In the work titled Blankets by Craig Thompson one can directly see the strong gestural marks Thompson makes with his brush and pen. The lines he creates add a tension to the book and create movement between the characters and the dialogue. I look to these artists for formal cues because of their intentional mark making similar to my work, these artists create and individualized narrative that embrace both satire and heart felt emotion.

Concert poster art is another source of influence that I look to when discovering new ways to tackle the surfaces of my functional utilitarian ware. French historian Max Gallo states that "For over two hundred years posters have been displayed in public places all over the world. Visually striking, the posters have been designed to attract the attention of passers-by, making us aware of a political viewpoint, enticing us to attend specific event, or encourage us to purchase a product or service." 15 Several concert music poster artists that I look to for inspiration is Jay Ryan of The Bird Machine (Fig. 15), Matte Stephens (Fig. 16) and Oliver Jeffers (Fig. 17) because of their flat graphic drawing styles.

13 Wolk. "Reading Comics: How Graphic Novels Work and What They Mean." (Cambridge: Da Capo Press, 2007) 203.

${ }^{14}$ Brown. "Cat Getting Out of a Bag and Other Observations." (San Francisco: Chronicle Books, 2007)

${ }^{15}$ Gallo. "The Poster in History." (New York, W.W. Norton and Company, 2002) 6. 
However, what I enjoy most about their work are the color pallets. Each of these artists use a muted range of color that changes the emotional bearing and adds a sense of antiquity to their work. The color choices I make are also derived from antiquity. I chose to use muted colors because of the memories I have of my grandmother's avocado colored kitchen appliances and the pastel yellow and green dishes that sat in her cupboard. Reflecting on my childhood comforts, I place similar colors on my pots.

\section{Pottery Influences}

Historically, I am influenced by ceramics from Mesoamerica especially Mayan Codex vessels (Fig. 18). Mayan codex vessels were covered with drawings that highlighted Mesoamerican ballgames, rituals and death. ${ }^{16}$ The drawings wrap around the form in its entirety and contain motifs and objects that inform the viewer of the daily life and ritualistic practices of Mayan society. When I first saw these vessels I was amazed at the intricate yet stylized drawing style they possessed. Patterns and brush strokes lead the viewer around the form to develop a narrative based on the human and animal characters that are present in their culture. I still look to these historical objects for inspiration in both form and design.

Another historical tradition in ceramics that I am influenced by is the Italian Maiolica wares produced during the $15^{\text {th }}$ century (Fig. 19). Italian maiolica is sometimes referred to tin-glazed earthenware. Typically decorated in bright colors on a white background, it frequently depicts historical and legendary Italian and European scenes. ${ }^{17}$ Images are centralized and surrounded by floral

\footnotetext{
${ }^{16}$ Reents-Buget. "Painting the Maya Universe: Royal Ceramics of the Classic Period." (Durham: Duke University Press, 1994) 32.

${ }^{17}$ Cohen and Hess. "A Guide to Looking at Italian Ceramics." (London: British Museum Press, 1993) 15.
} 
and interlocking patterns. ${ }^{18}$ Italian maiolica was created as a way to imitate Chinese porcelain (Fig. 20) that was being imported to Europe during the renaissance period. I am drawn to not only the decoration style of Italian Maiolica but I am also attracted their forms. Many fine examples of Italian Maiolica appear on plate forms (Fig. 19) which gives the maker a large, flat surface to decorate. Furthermore, in the albarello form, or pharmacy jar (Fig. 21). An albarello is a tall cylindrical form that often has banners with text. This simple form allows the decorator ample drawing and decoration spaces.

When viewing and using contemporary ceramics I am most inspired by handmade utilitarian functional objects. I find inspiration in the work of ceramics artists Linda Christianson (Fig. 22), Simon Levin (Fig. 23/24), Brian Jones (Fig. 25/26) and Ayumi Horie (Fig. 27/28) it is not the depth and layering of the surface but the forms and philosophies of making that draw me look to these artists for inspiration. My work is very different from the atmospherically fired work of Christianson and Levin but their work contains a beauty in functionality that I place in my work. Horie and Jones are inspiration because they employ imagery on their work. I look to these potters for cues on solving potential problems when putting images on pots.

The work by Christianson and Levin beg to be used by people and function in one's home on a daily basis. They are beautiful objects in both the aesthetic arena and in terms of functionality. Levin states, "It is in the home, rather than an artistic intuition, that I feel we potters should exploit. A cup is one of the first things we hold in the morning, and often one of the last things we touch at night. By introducing artistic ware into the home we can reconnect art and the everyday." 19 As a potter making functional ware for the home the words spoken by Levin in his artist statement are dear to my heart. It is my goal as a maker of utilitarian pots to put my work in the homes of people. However,

${ }^{18}$ Cohen and Hess. "A Guide to Looking at Italian Ceramics." (London: British Museum Press, 1993) 15.

${ }^{19}$ www.simonlevin.com 
it is not enough for my work to be in a person's home as it must function in a way that I, the maker, intended. It is my belief that the daily use of an object at it was intended defines the object a good piece of pottery.

Brian Jones, a potter from Portland Oregon, creates functional utilitarian pottery that utilizes earthenware and simple drawings. Jones states in his artist statement that the inspiration for his work comes directly from memories he has from his childhood especially the use of the pots that come from his grandmother's house. ${ }^{20}$ Jones believes that the pot is both a reservoir and an initiator of memories. ${ }^{21}$ It is through the use of objects in the home that relationships start to form with those objects. Once people find and discover a relationship with an object, memories start to form around those objects and they become treasured. As a potter I want my objects to become a treasured bridge between the handmade objects and treasured memories.

My pottery revolves around the idea of capturing fleeting moments and the importance of physical and psychological comfort. Like Christanson, Levin, Horie and Jones, my pots are made to aid in nourishment as containers for serving and storing food and drink. As well as providing a physical comfort. Holding a mug or a bowl in one's hand places the object in the personal space of the user. When the forms are smooth and rounded the form becomes more physically comforting. Psychologically, the surface decoration my pots capture can give the viewer comfort. The questions that I pose on the surface are universal statements and questions. By placing the text on the surface I am aiding the viewer by psychologically making them not feel as if they are the only person with these questions or concerns. The cute animals also psychologically add comfort make the questions and statements more digestible.

\footnotetext{
${ }^{20}$ www.brianrjones.com

${ }^{21}$ www.brianrjones.com
} 


\section{Chapter 3: The Rationale for Ridiculous}

The internal monologue that plays inside my head was the main culmination of my MFA research. During my time in graduate school, I experimented with the use of cute and text on functional utilitarian pottery and discovered what tools and knowledge was necessary to make good pots. My role is to make good pots and people in mind while making them. The user is what dictates and decides what is a "good" pot or a "bad" pot. Through making this work I began to wonder if pots and the messages that pots tell could have a greater impact on a social setting especially if the objects begin to question one's existence and role in society.

The text on my pottery comes from my daily questions pertaining to my life and my role in society. I keep notes and lists of text in my sketchbook. I refer to the lists when choosing text for my pots. When looking through the lists of quotes to use, I am reminded of the situation that the conversation or spoken phrase first appeared and I discovered while making this work that I am not the only person that can relate to the text placed on my pots. I began placing phrases on my work that question my future upon leaving graduate school and the heartbreak that I will feel when leaving a place that I have become fond of. When writing the text on my pottery I begin to think about how ridiculous it was that I was placing my greatest insecurities on my pots. I placed the text in banners as a way to celebrate the fact that I was giving into my thoughts and making them a reality on ceramic vessels. Exposing, myself with the texts directly on my work, it was through the use of a blue rabbit and a yellow cat, on the same surface, that I found comfort. The comfort in what I was revealing through the text was weaving its way onto my work because of the personal attachment and association that begin got occur on the surface of my pots.

"This Will Get Me Though the Day" is a large mug installation consisting of 43 mugs each hanging from an individual wall peg (Fig. 29). The spontaneous 
hanging style on the gallery wall partially conceals the messages in which the mugs are exposing and the text becomes a hum of irregular thought. Each mug represents singular time specific thought. However, because they are threedimensional objects, messages become hidden due to the wall masking the back of the mug. For the viewer to fully interact with this object he or she must remove the mug from the wall and engage the mug in his or her own personal space. The ritual act of drinking coffee that will help me get through the day is analogous as questioning nature that also helps me get though my day

In my work, titled "Morning Maker with Informational Receiving Antenna" (Fig. 30) and on bottles sets called "They Say Practice Makes Perfect" (Fig. 31 ). I choose to use luster on these pieces because of the over the top golden garish quality that luster presents. Luster was important for these pieces because conceptually it refers to antennas. The text that appears on these objects is also specific for gatherings. They are statements that pertain to not only the importance of gathering and spending time with individuals but the text also questions the necessity of social gatherings at certain times and places. the sets require gatherings to the use object like the coffee pot. The coffee pots is large and a system of parts to brew the coffee. The size of the coffee pot is appropriate for gatherings of people.

Another goal that I had was to represent chatter and the overwhelming bombardment of questions that penetrate my life. "Collective Joy for the Masses," (Fig. 37) a large plate installation attempts to do just this. The plate when placed on the wall becomes a confrontational two-dimensional object. Messages are no longer hidden from a viewer but the message is thrown directly into the face of the viewer. The plate installation is meant to confront the viewer with my questions. "Collective Joy for the Masses" questions my relationship with people in my life and my fears about leaving treasured relationships and voluntarily disrupting my home setting. Phrases such as "this will never get easier" and "I will miss you when I'm gone" decorate these pots to 
give me comfort. It never gets easier when leaving a setting that I have become attached to however it is the questions that I pose in my head that gives me comfort and through this knowledge understand that I will return to the special places I have in my life.

"Sometimes the Answers Are Hard to Find" (Fig. 38) and "A Little Scrubbing Might Solve the Problem" (Fig. 37) also incorporate plates however, contrary to the installation "Collective Joy for the Masses" the plates in these two pieces are held in dish racks commonly seen next to a sink. My intention was to reference the home/kitchen and make the viewer search for the questions that appear on each individual plate. I choose to use plates for their flat surface and single-sided decorated surface.

The text and imagery on the plates become obscured in the dish rack because of the over-lapping of the amassed objects. For a person to establish what the plates represent/questioning the viewer must alter his or her own position, bend down in an uncomfortable manner. Obscuring the text due to the over-lapping forms also reflects my own tendency to hide the truth from others. I would never vocalize the phrases on my work such phrases people and would never share my actual feelings with complete strangers in the way that the plates state my feelings and emotions to viewers but by hiding the text, the viewer must spend time with the installation to view and understand the pieces. 


\section{Chapter 4: Conclusion}

My time spent in graduate school proved to be a rediscovery and revival of myself, not only as an artist, but also as an individual in a creative society. My work demonstrates a new found confidence in my abilities to create but also confidence in my beliefs, ideas and purposes. Through my pots, I intend to physically and psychologically capture and draw attention to the fleeting moments in life. My pots are thrown on the wheel and decorated with drawings of animals and text filled banners. The animals are comforting icons from my childhood, while the banners reference celebration and the text reflects my inner monologue that emotionally questions my purpose. As a graduate, I feel confident in my work's relevance in the contemporary art world. Making good pots is something that I will always strive to achieve. 


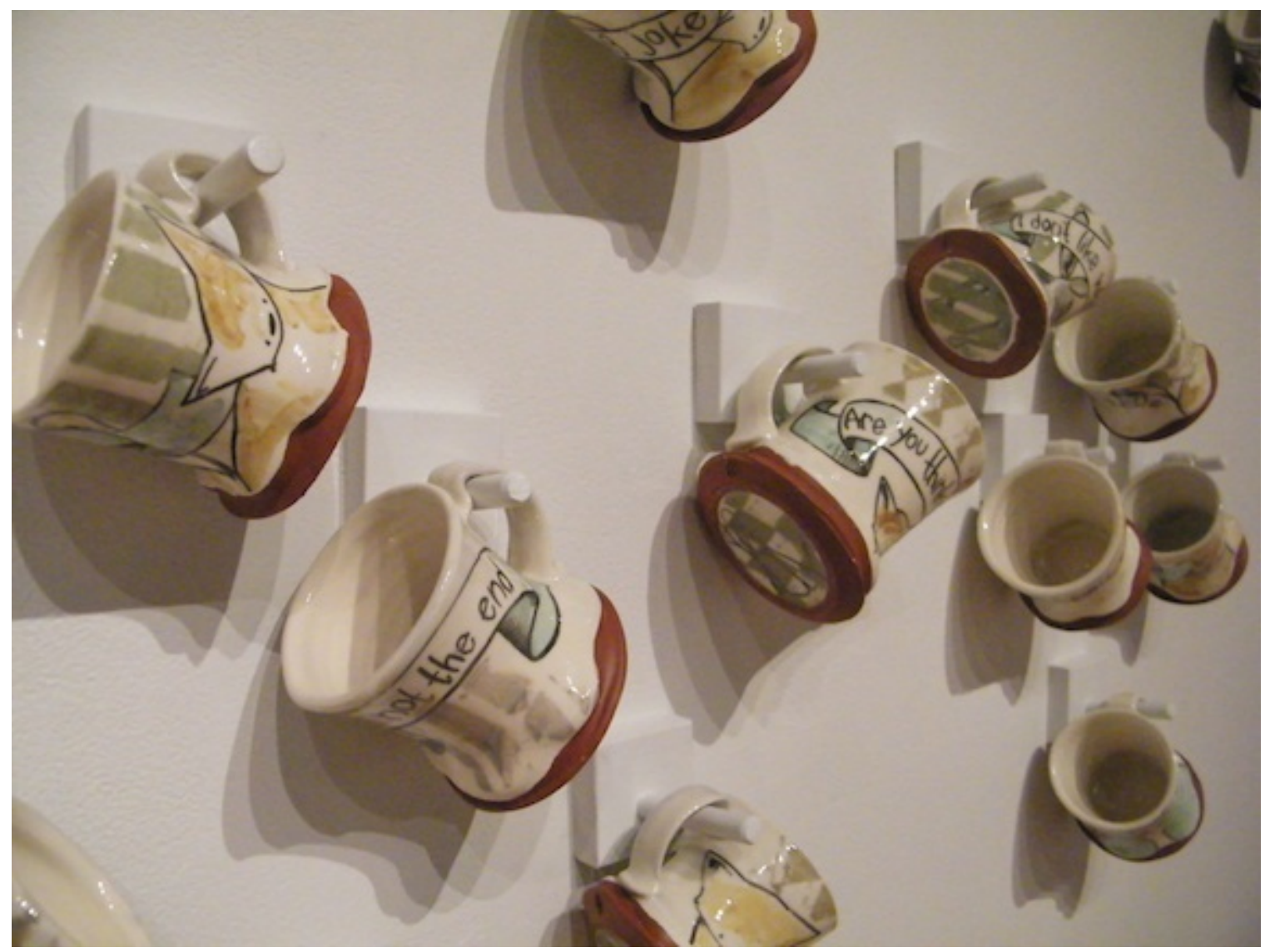

Figure 1. This Will Get Me Through My Day Mug Installation

Earthenware

2014 


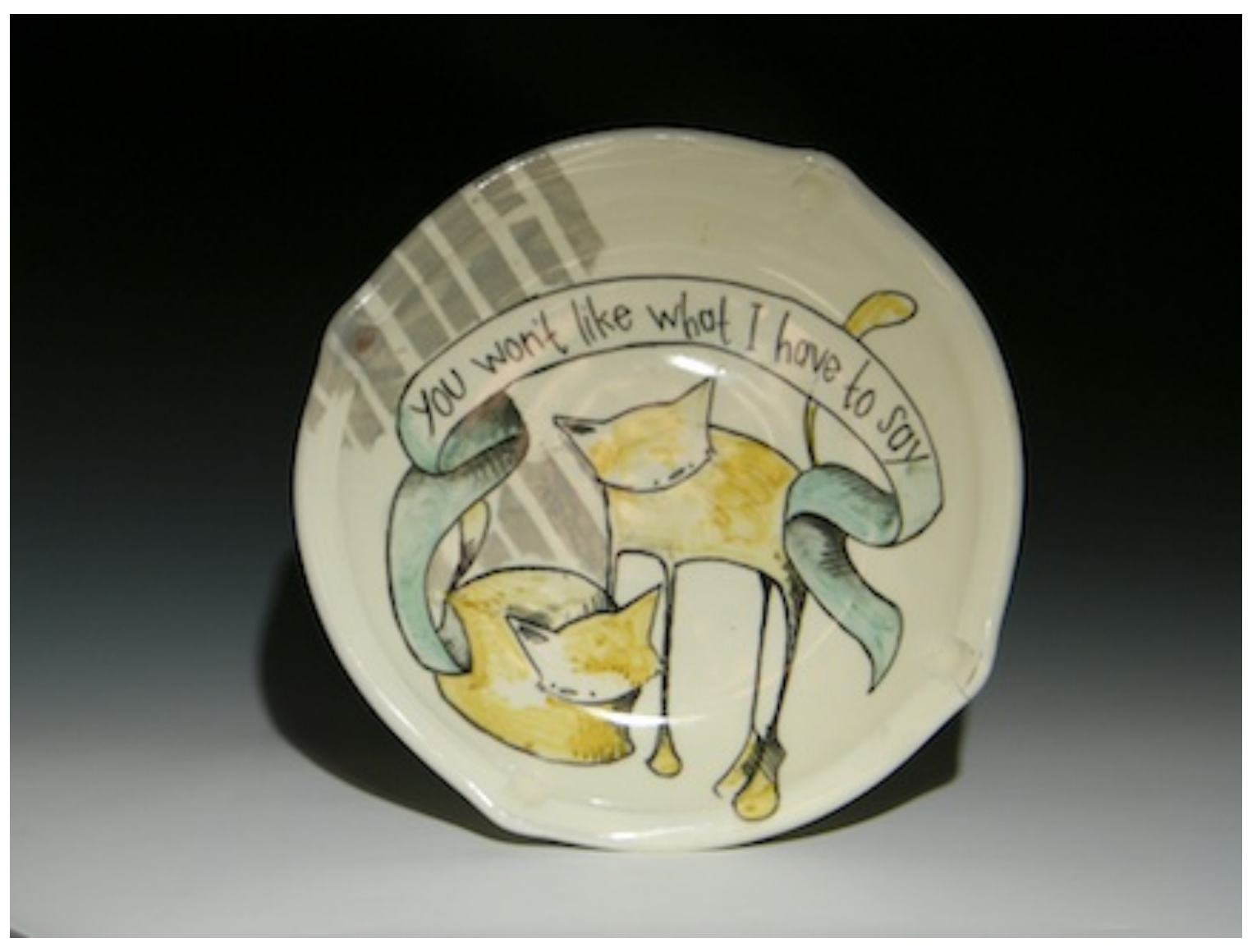

Figure 2: Sassy Snack Plate Earthenware 2013 

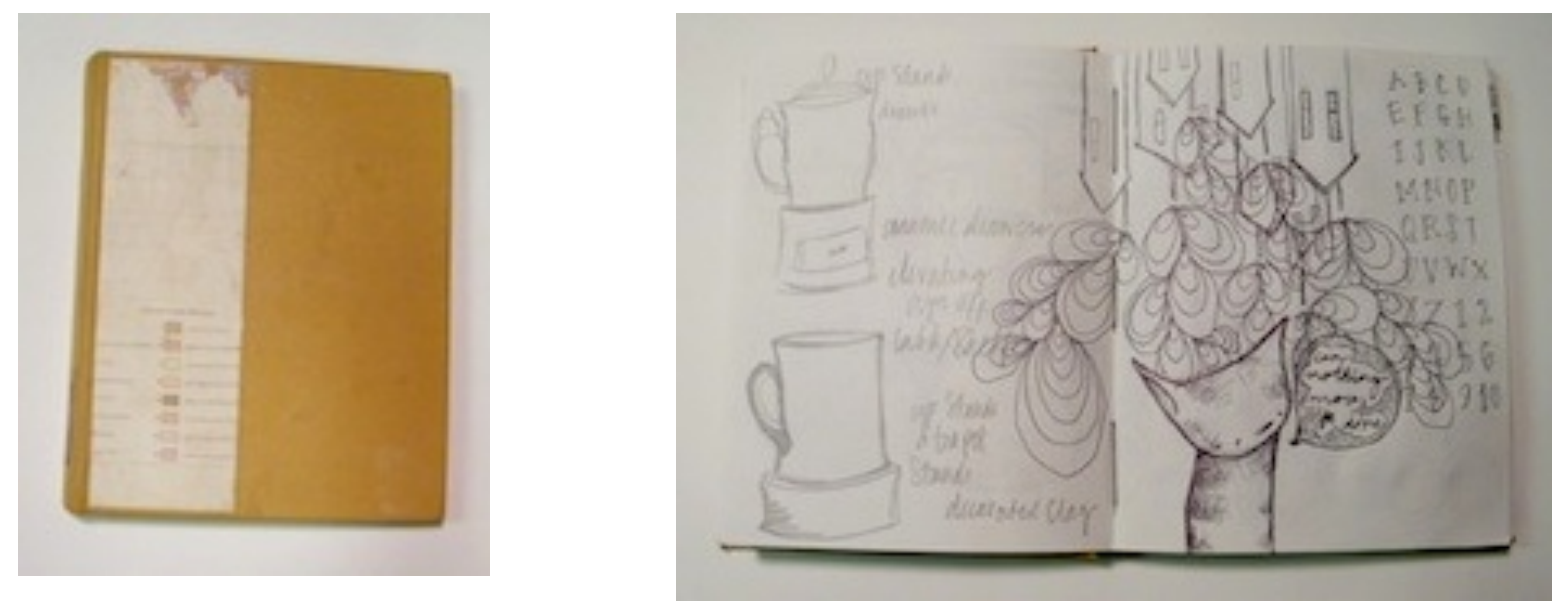

Figure 3: Vol. 1 (China Fall 2010)
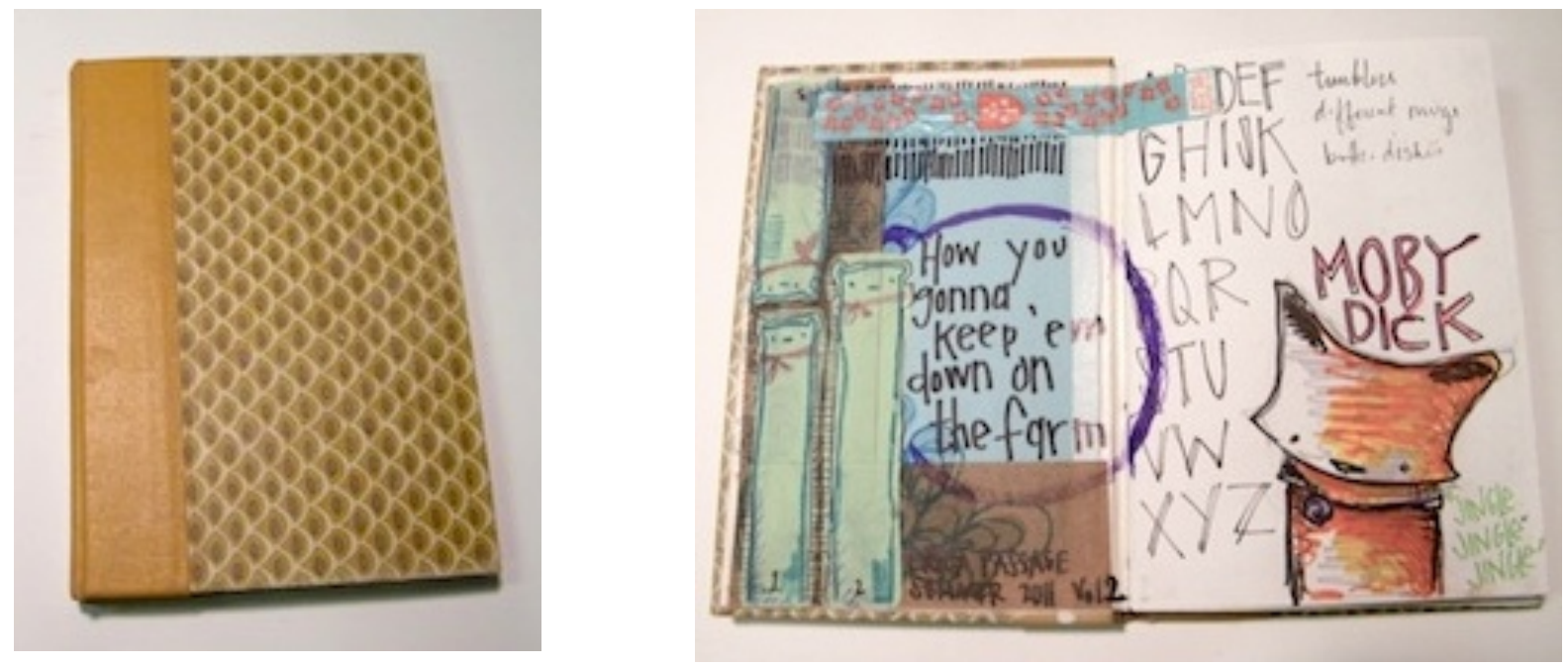

Figure 4: Vol. 2 (Spring 2011)
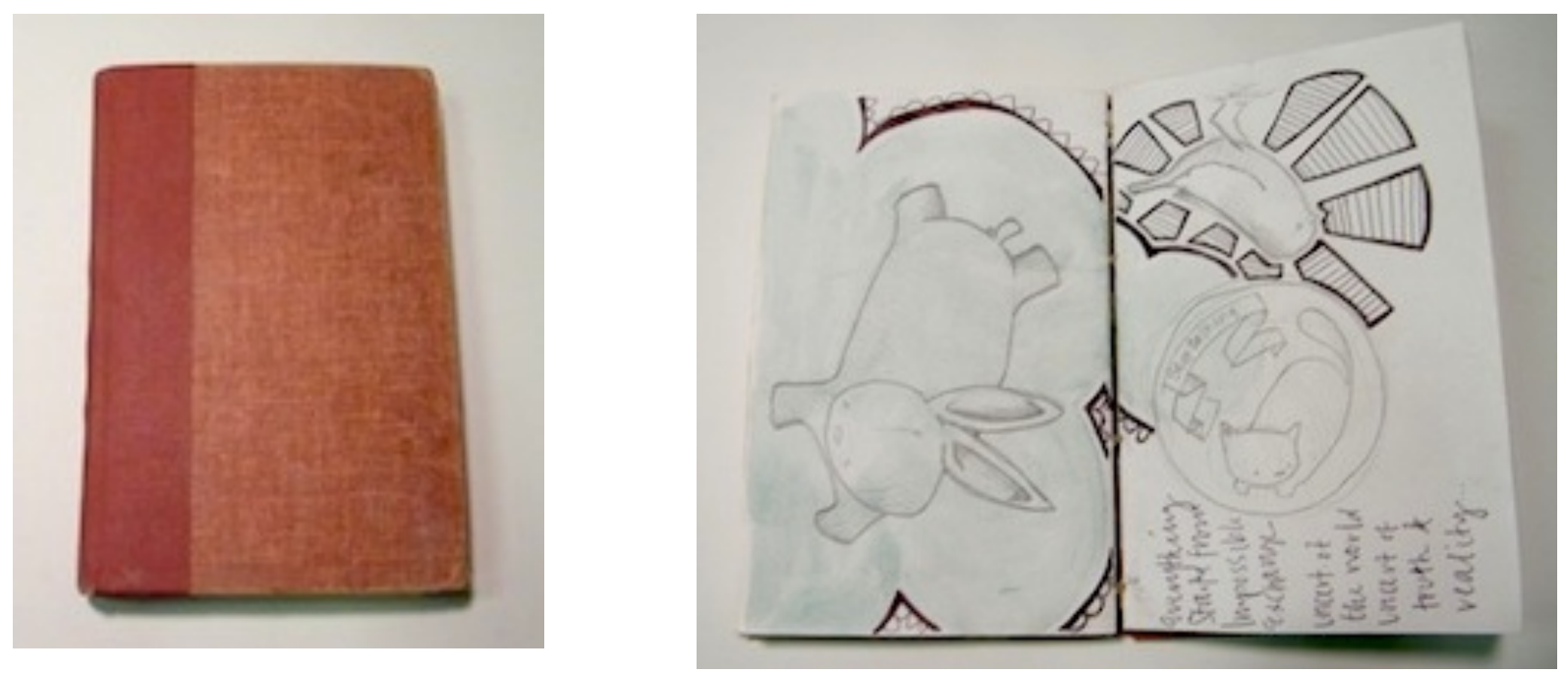
Figure 5

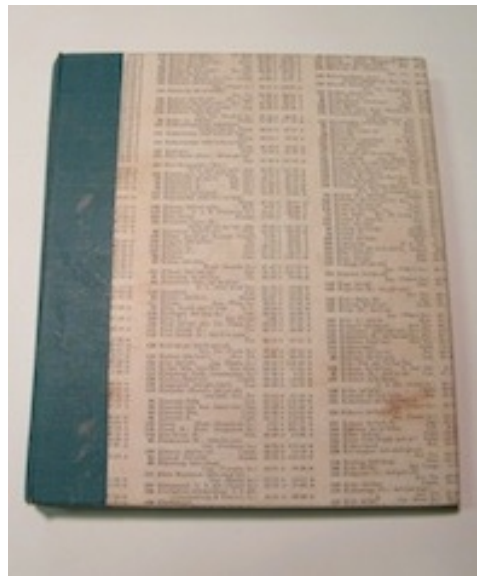

Vol. 3

(Summer 2011)

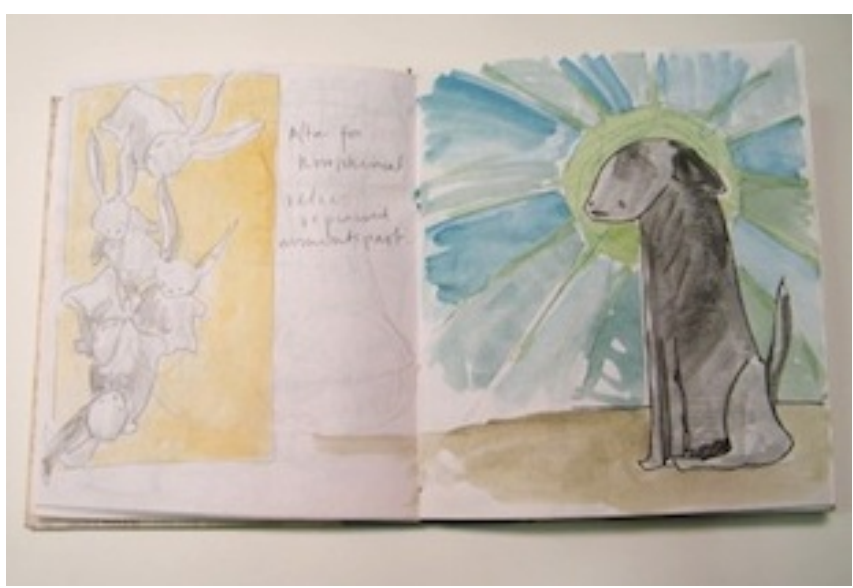

Figure 6: Vol. 4 (Fall 2011 and Winter 2012)

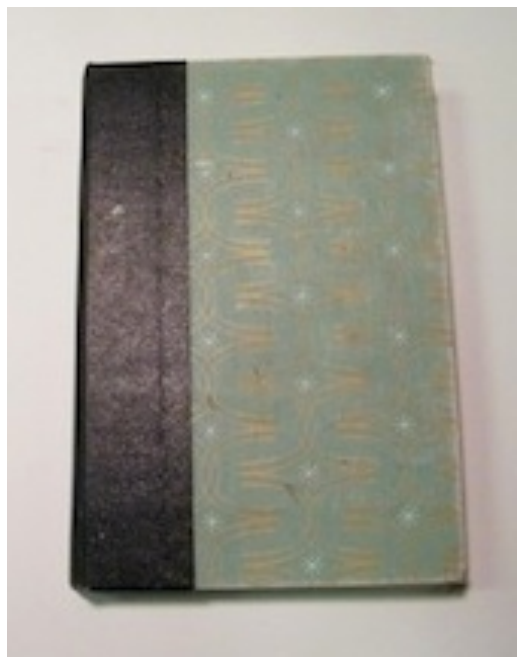

Figure 7: Vol. 5 (Spring 2012)

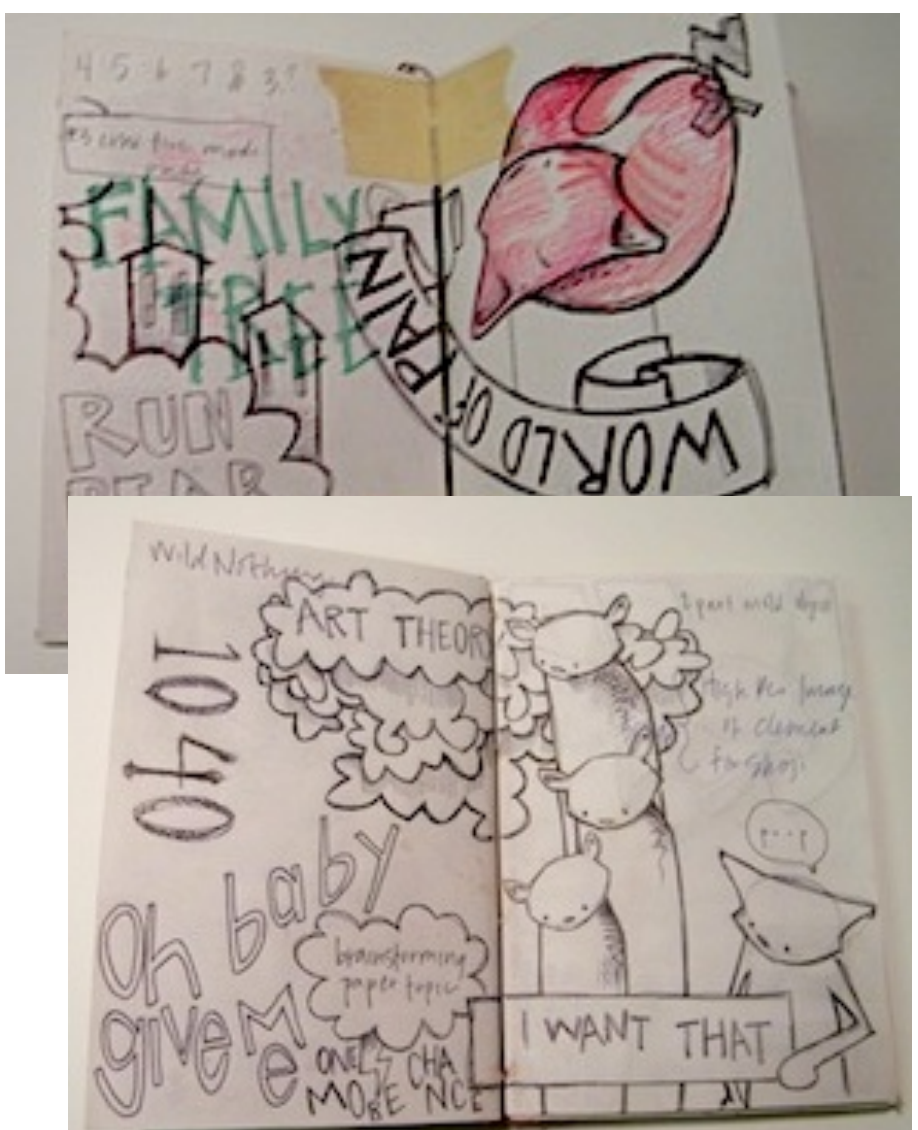




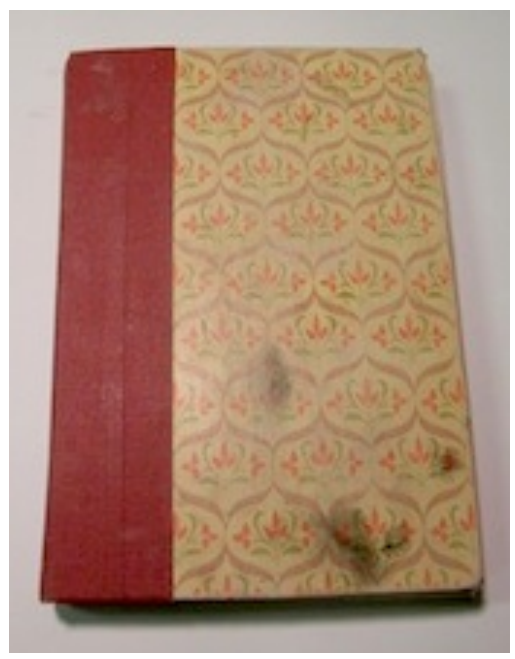

Figure

8:

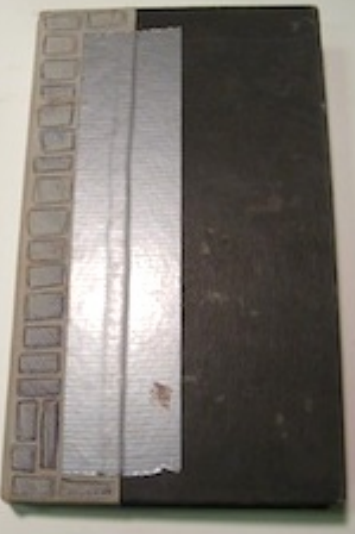

Vol. 6

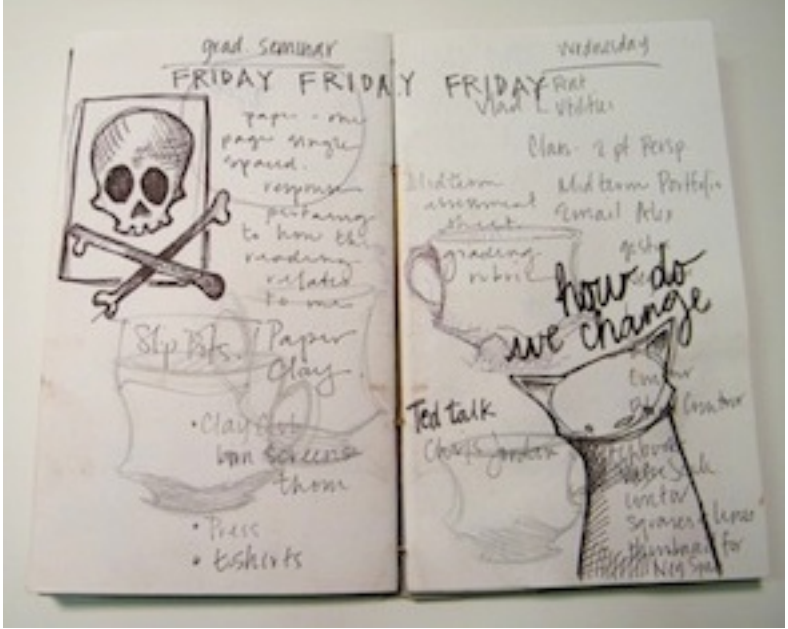

Summer 2012)

Figure 9: Vol. 7 (Fall 2012) 

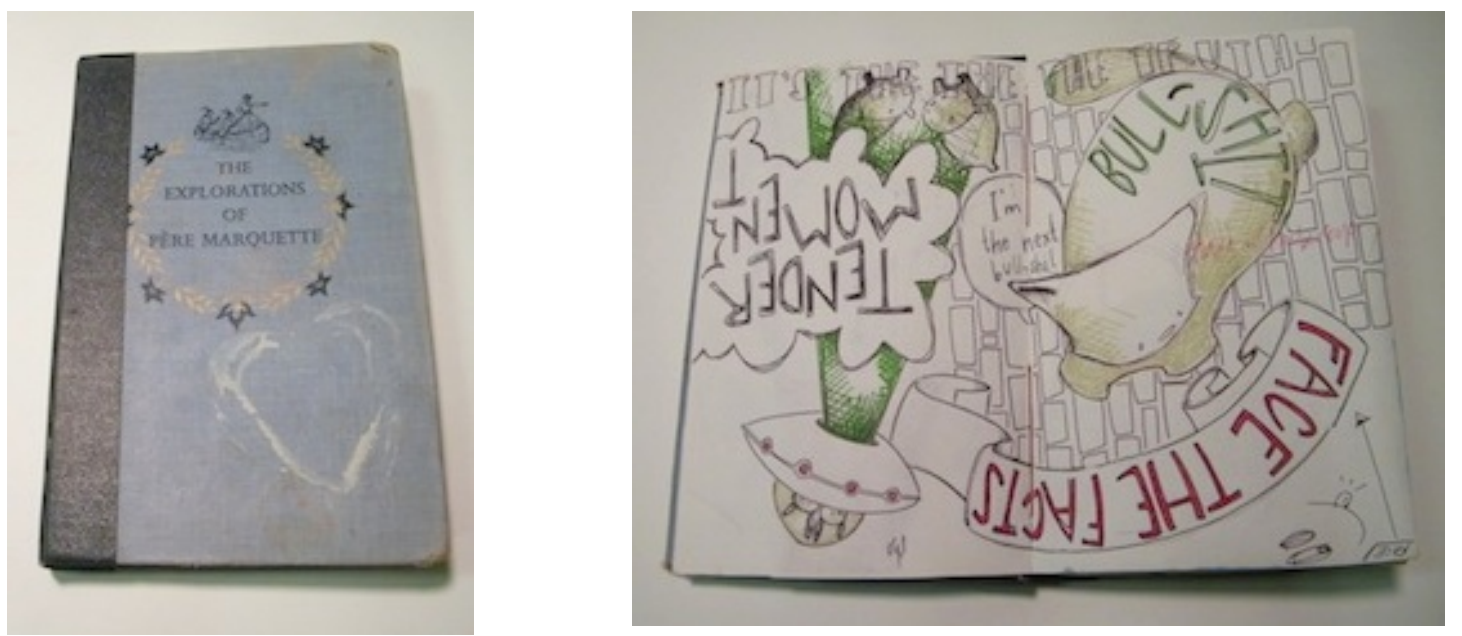

Figure 10: Vol. 8 (Winter 2013)
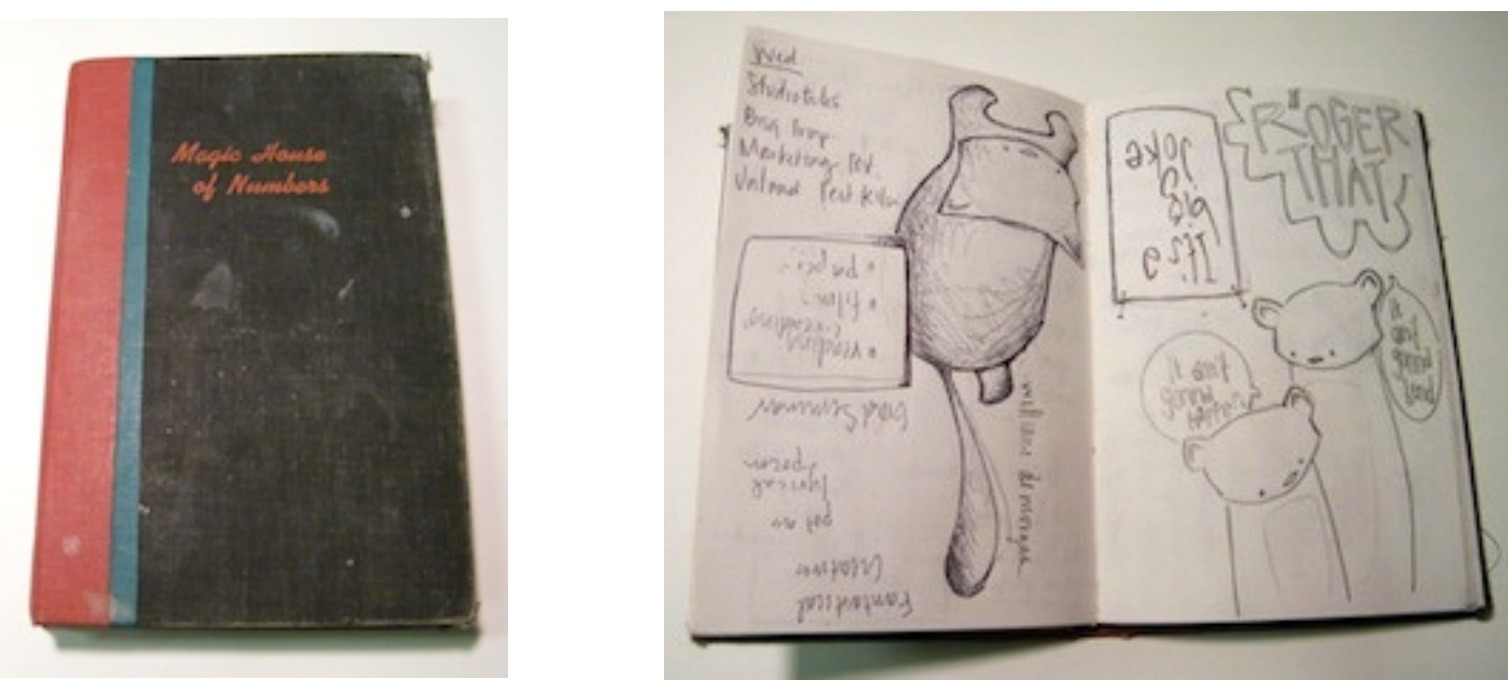

Figure 11: Vol. 9 (Spring 2013- current book) 


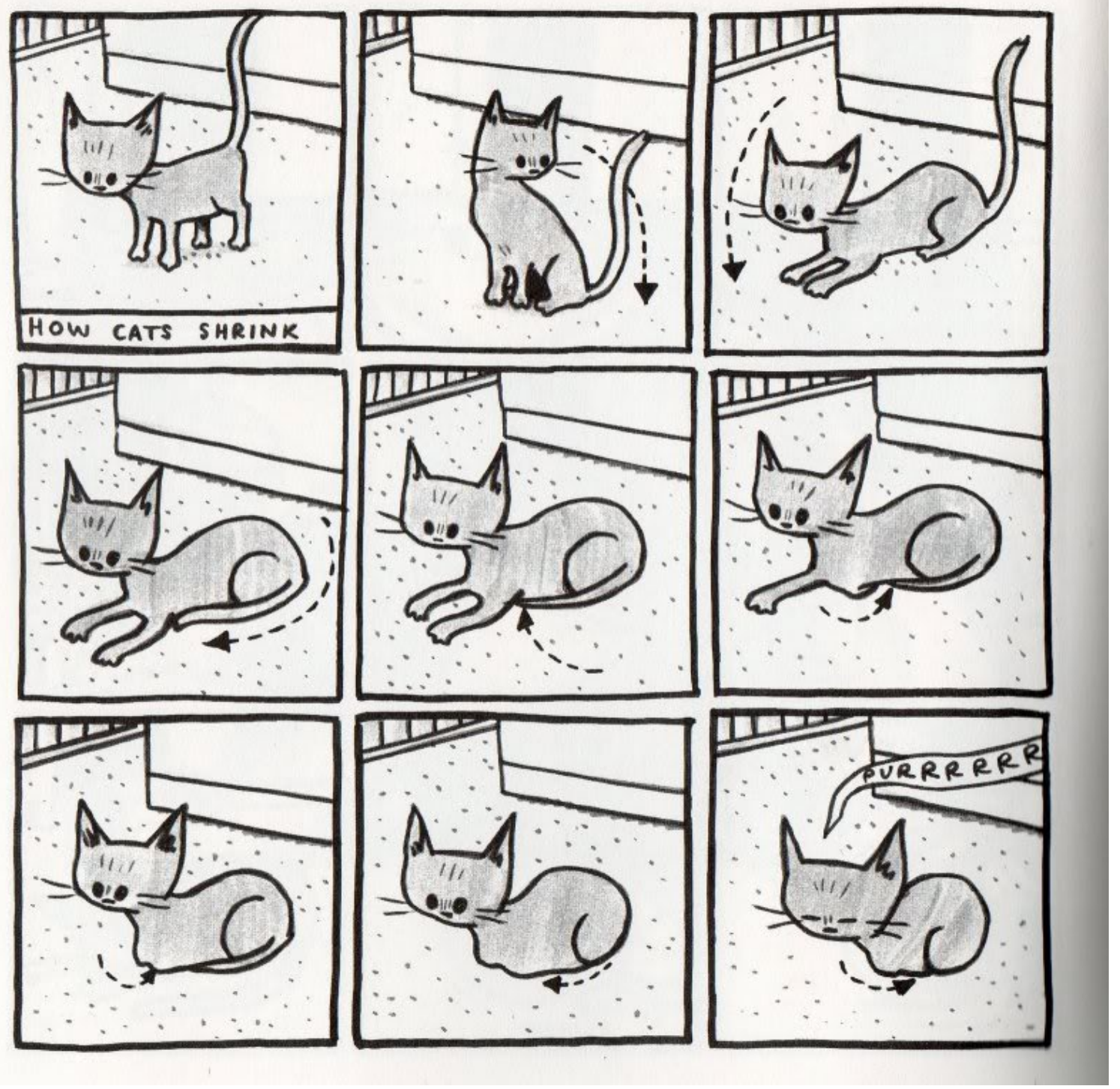

Figure 12: Jeffrey Brown

Cat Getting Out of a Bag and Other Observations

How Cats Shrink

Pen and Ink on Paper

2007 


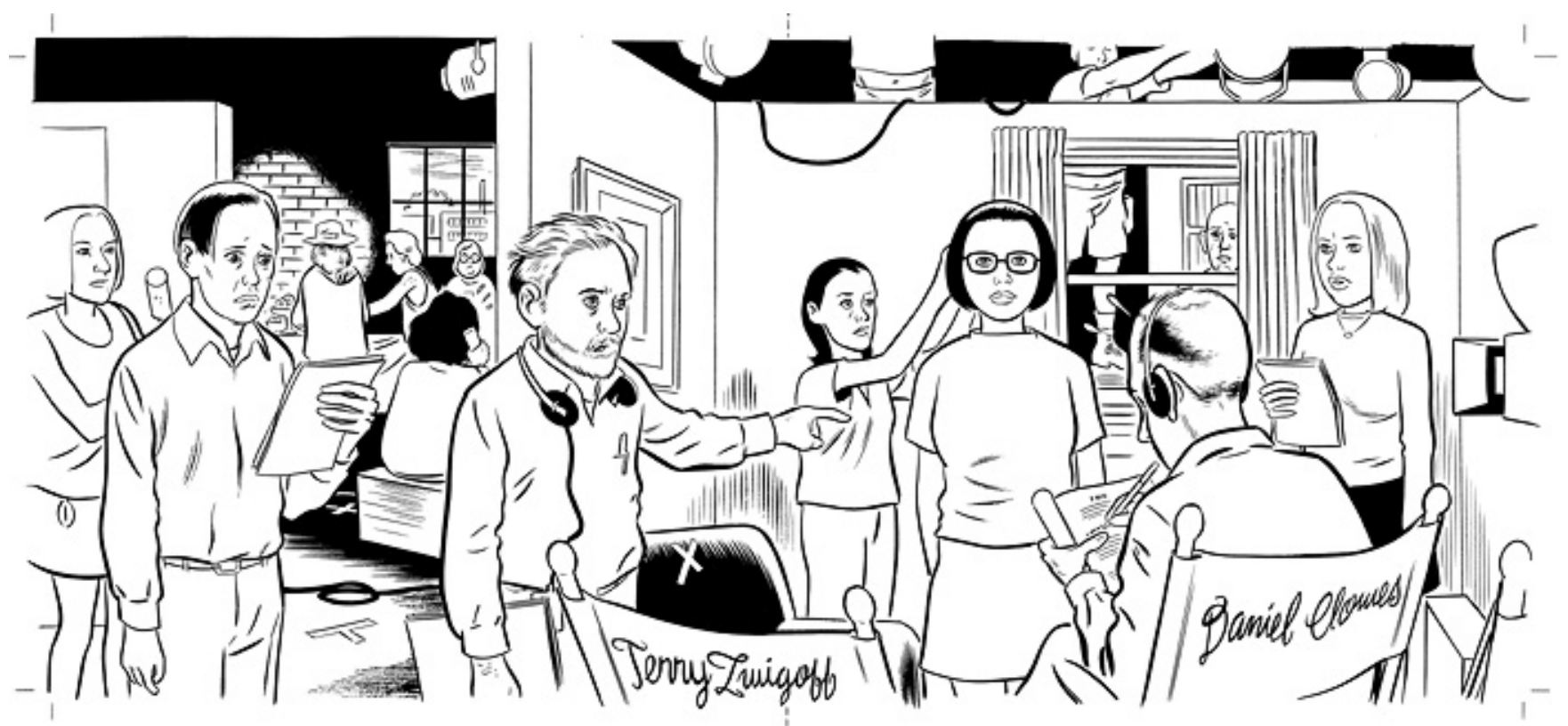

Figure 13: Daniel Clowes Ghost

Pen and Ink on Paper 2012

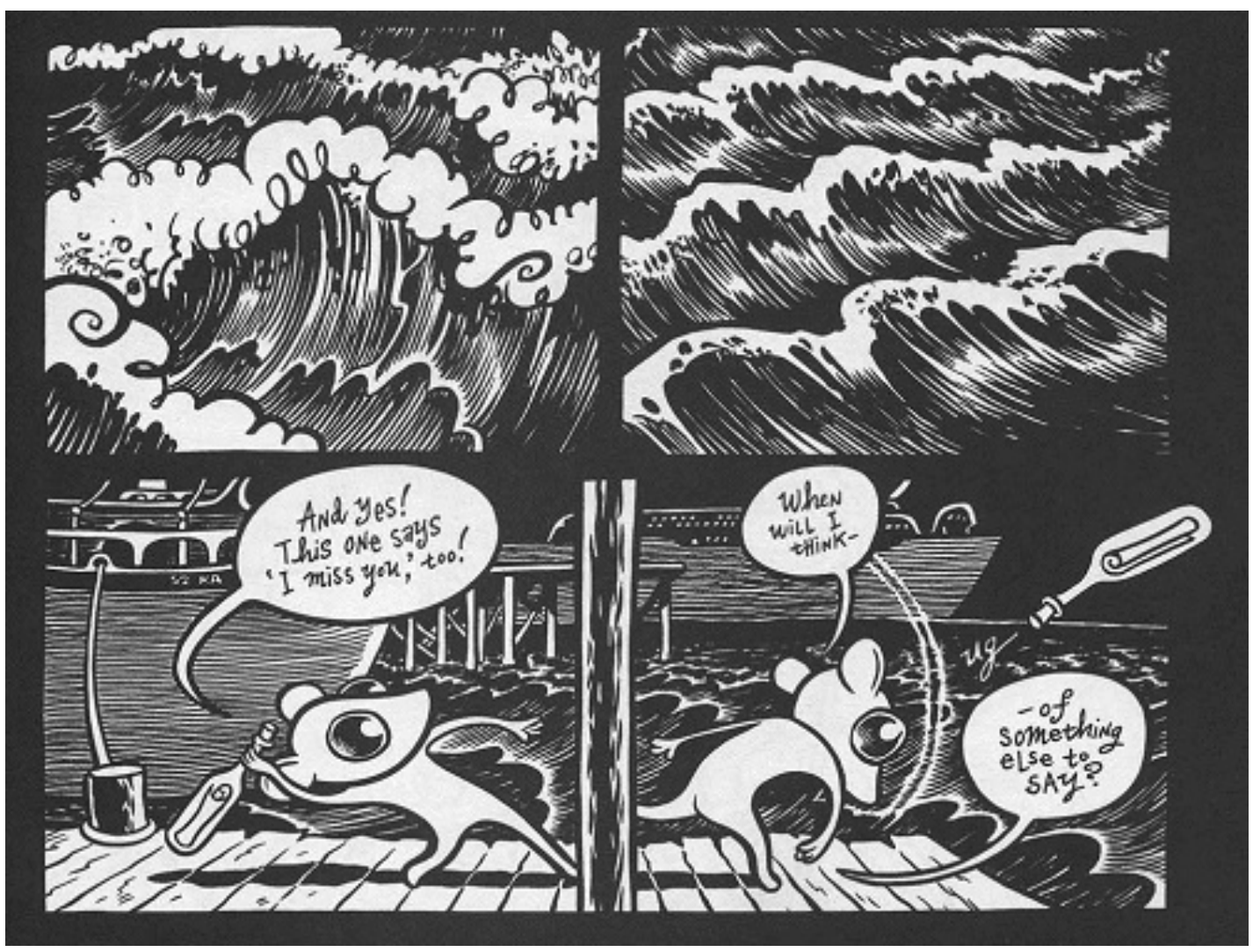

Figure 14: Craig Thompson Daily Comic Pen and Ink on Paper 2012 


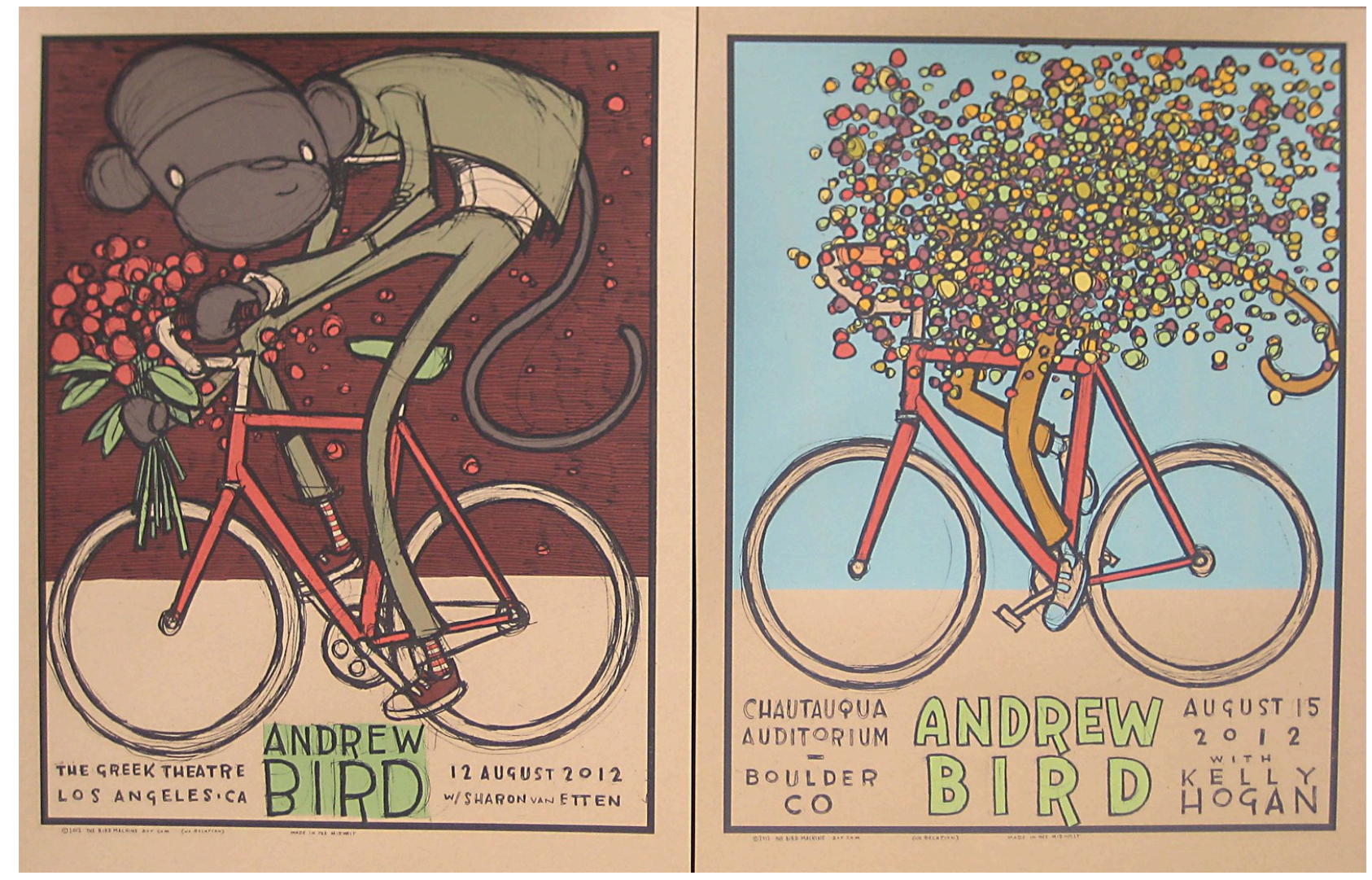

Figure 15: Jay Ryan

Andrew Bird Concert Poster Silk Screen on Paper

2012 


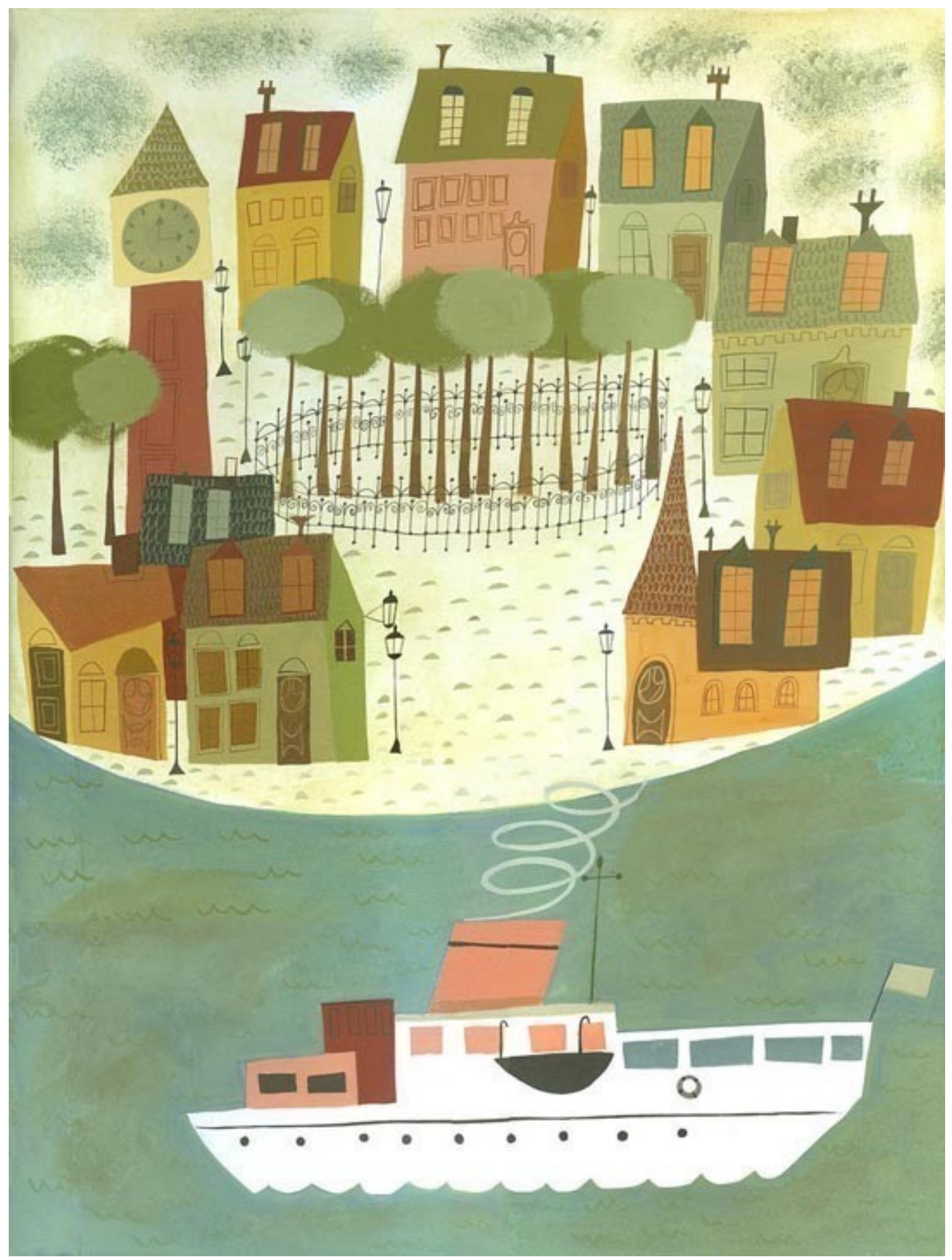

Figure 16: Matte Stephens

Nantucket

Gouache on Paper

2010 


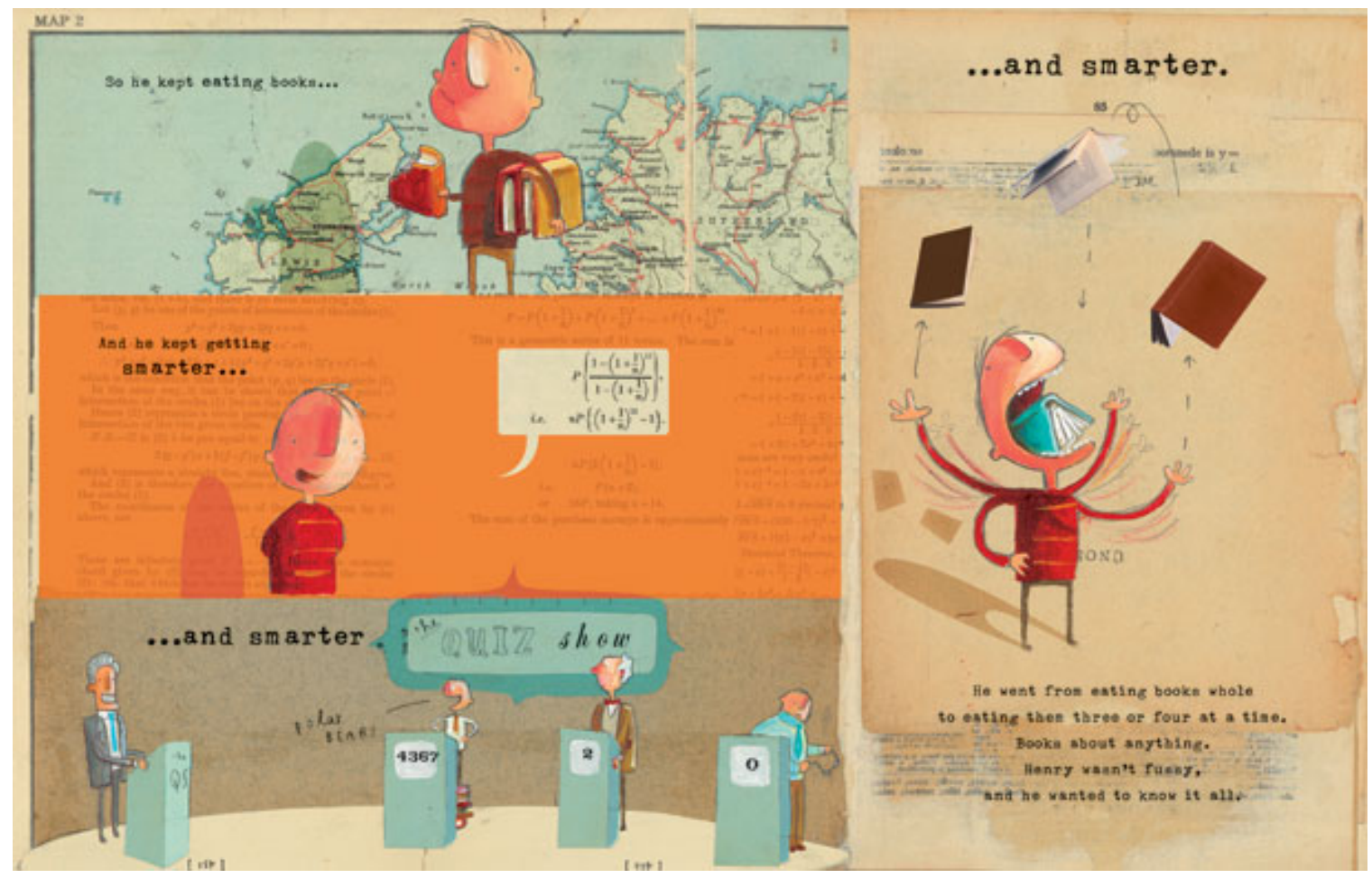

Figure 17: Oliver Jeffers

Map 2: Book Eating

Gouache on Paper

2010 


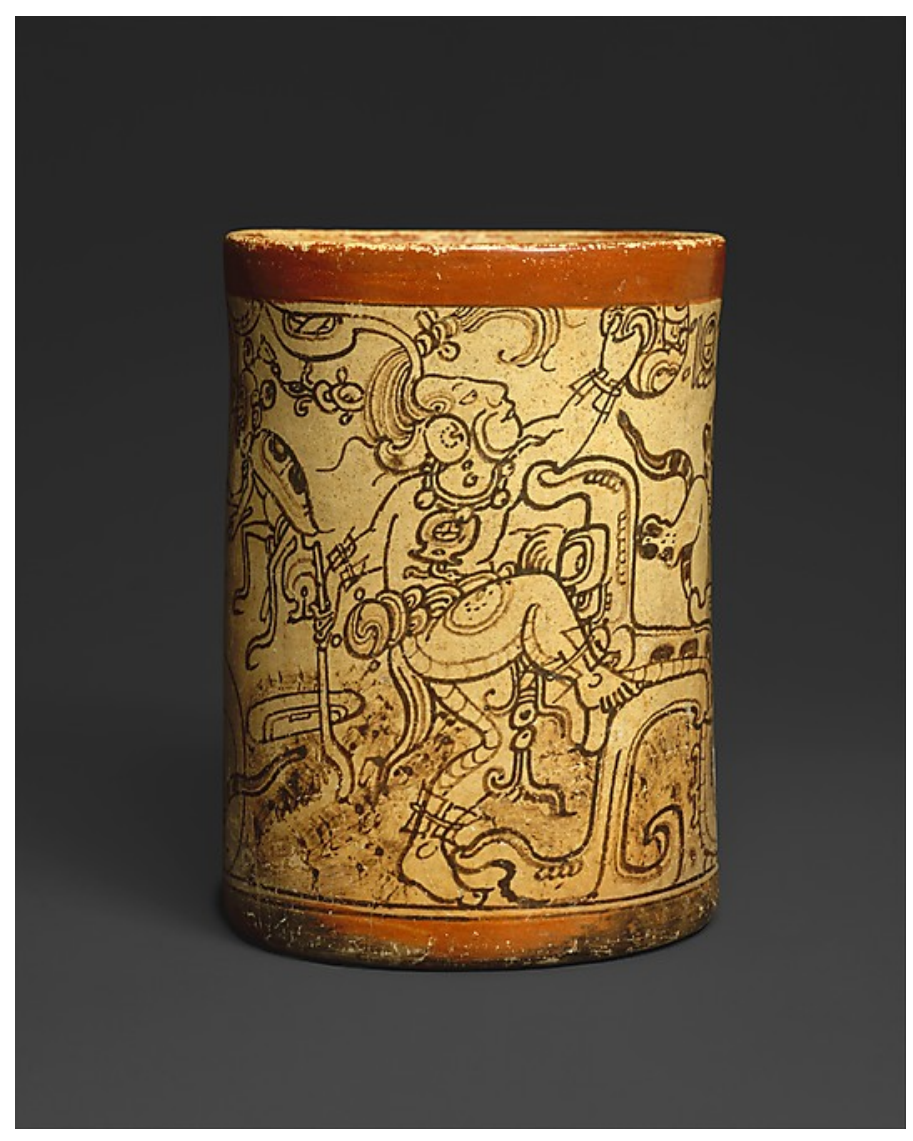

Figure 18: Mayan Codex Vessel

Earthenware

Late Class Period

550-700AD 


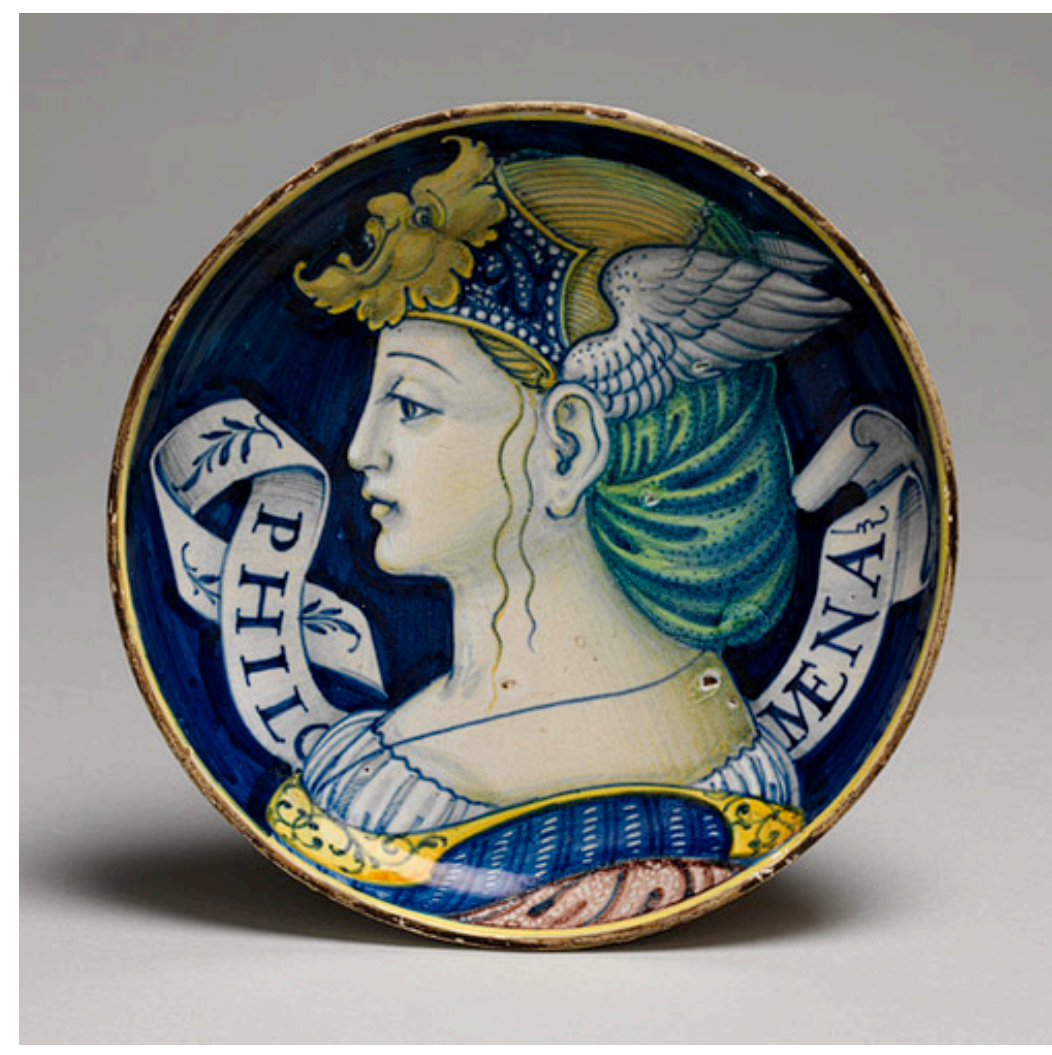

Figure 19: Pair of Low-Footed Bowls with Busts of Filomena and Ruggieri Italian Maiolica 1520-1525 Italy: Urbino Tin-Glazed Earthenware

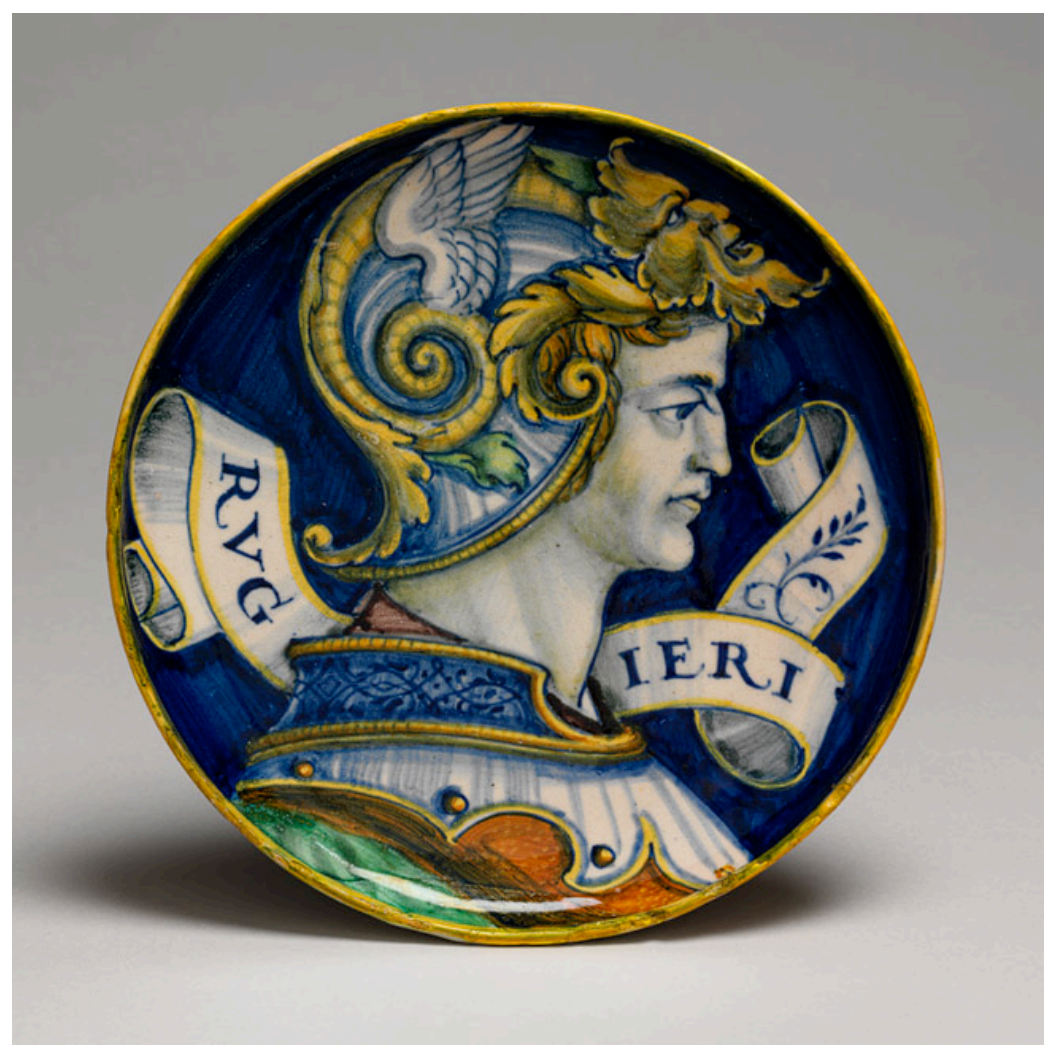




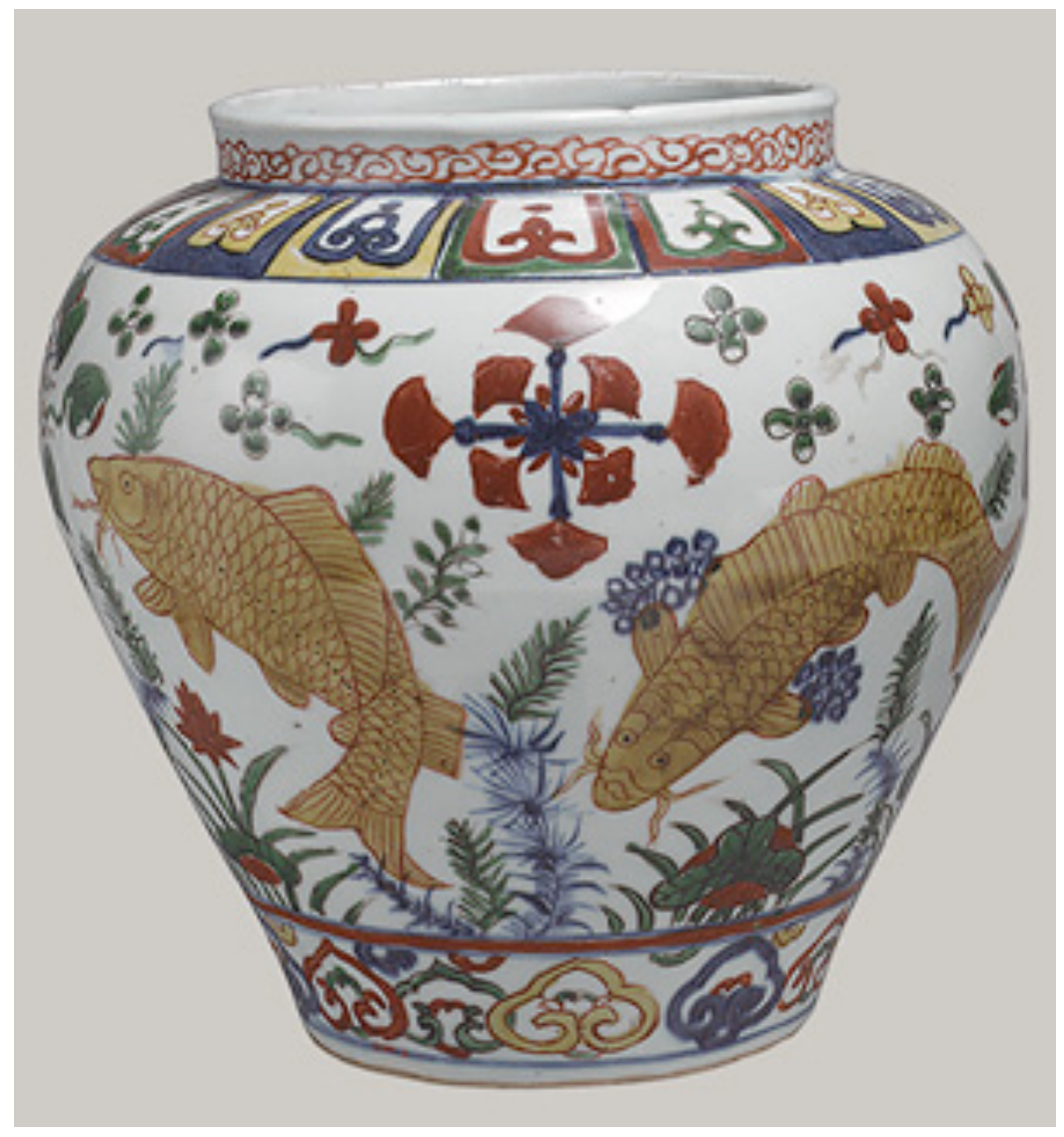

Figure 20: Ming Dynasty Jar

Porcelain

1522-1566 


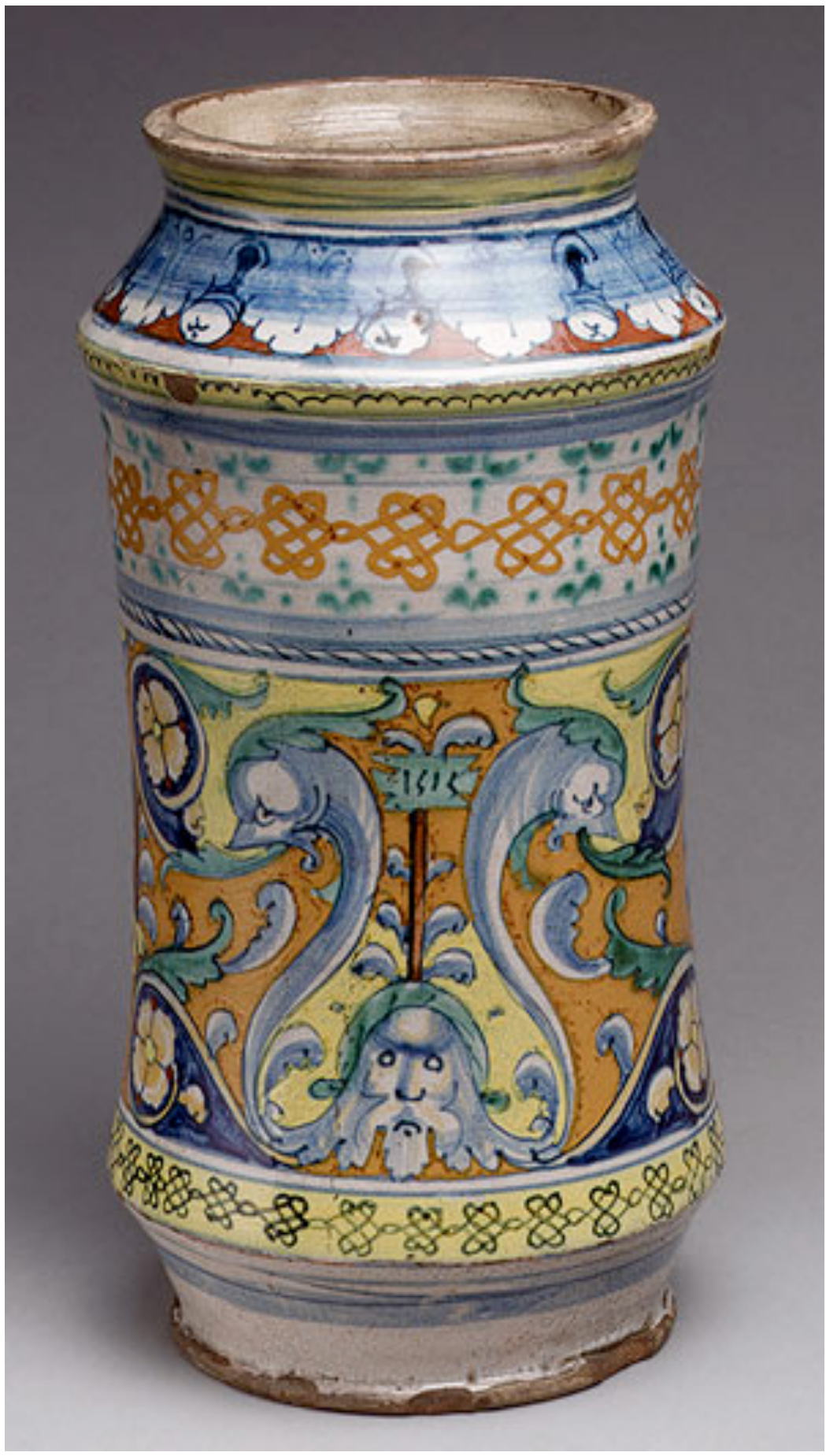

Figure 21: Pharmacy Jar Tin-glazed Earthenware Italian: Siena

1515 


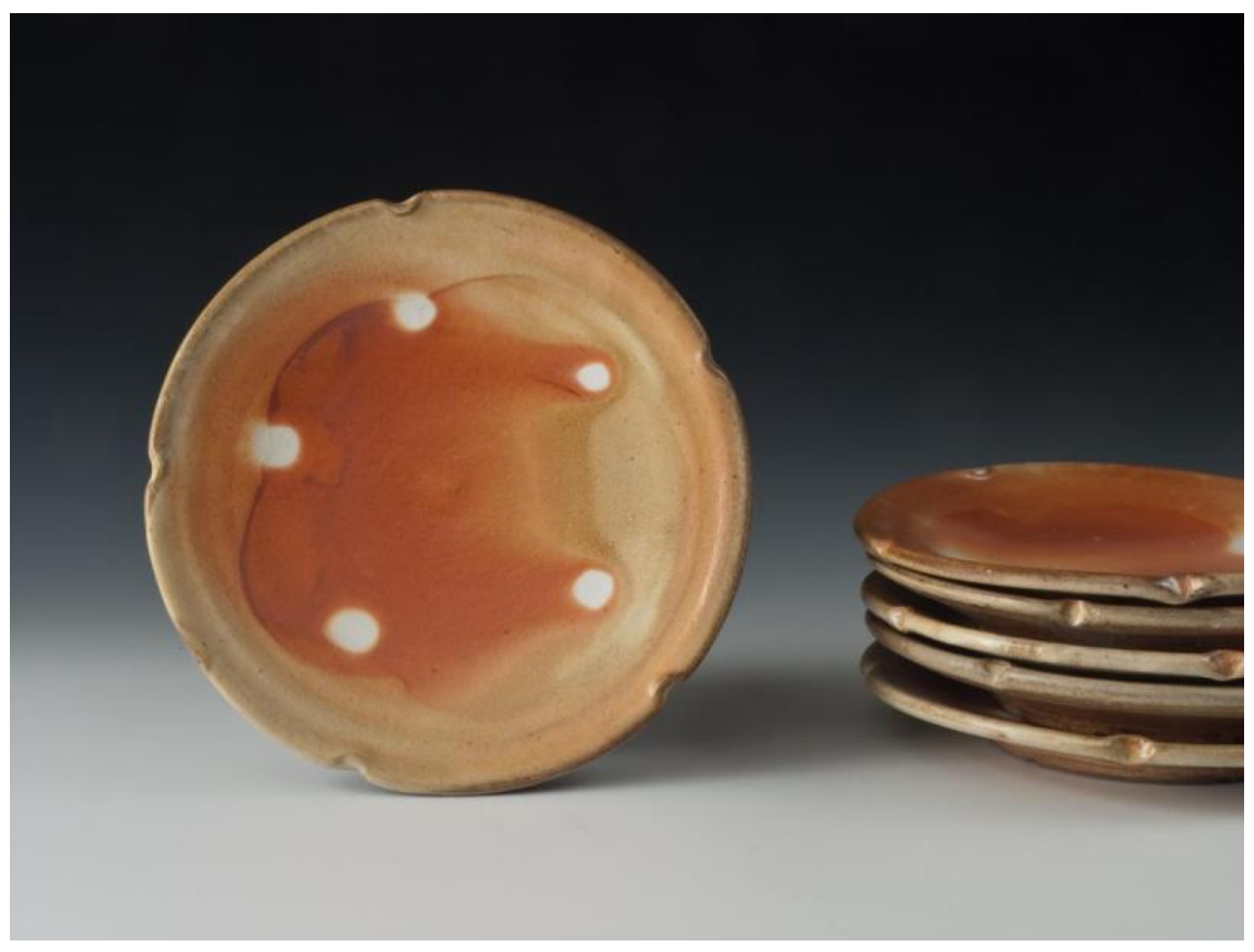

Figure 22: Linda Christianson

Halo Plates

Porcelain

Wood-Fired

2010 


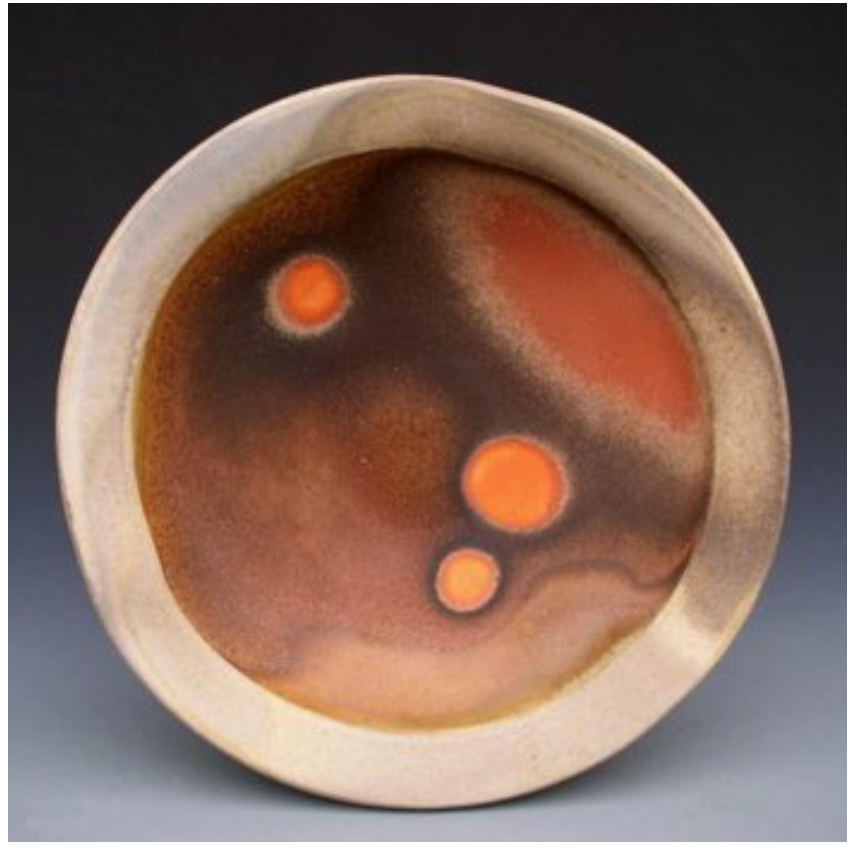

Figure 23: Simon Levin

Plate

Porcelain

Wood Fired 2010

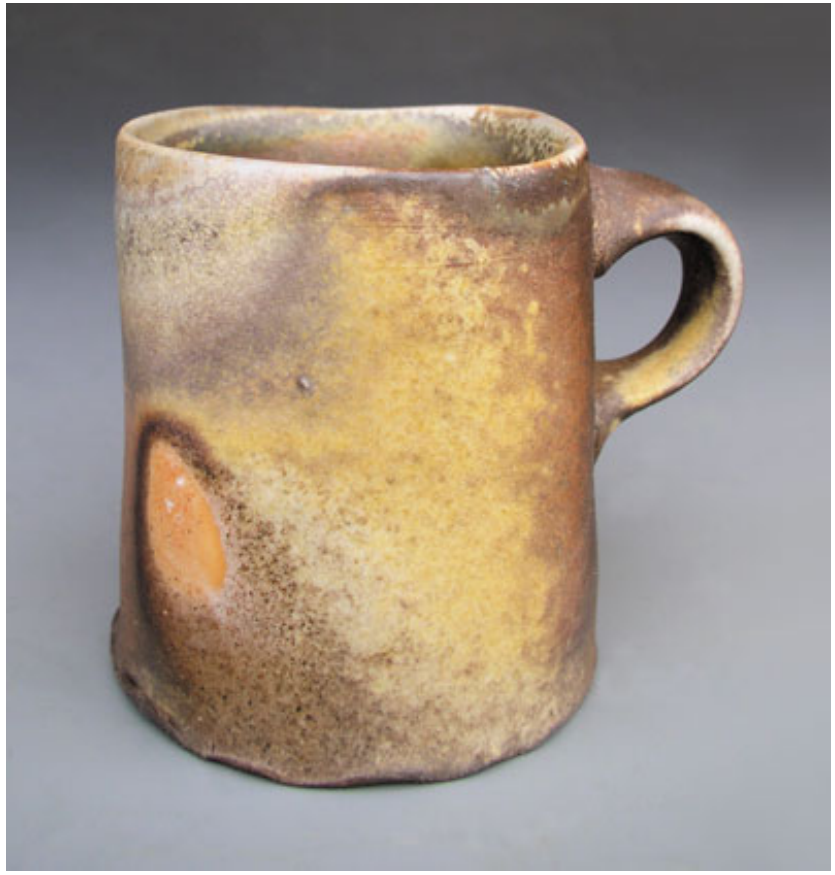

Figure 24: Simon Levin Espresso Mug Porcelain Wood Fired 2005 


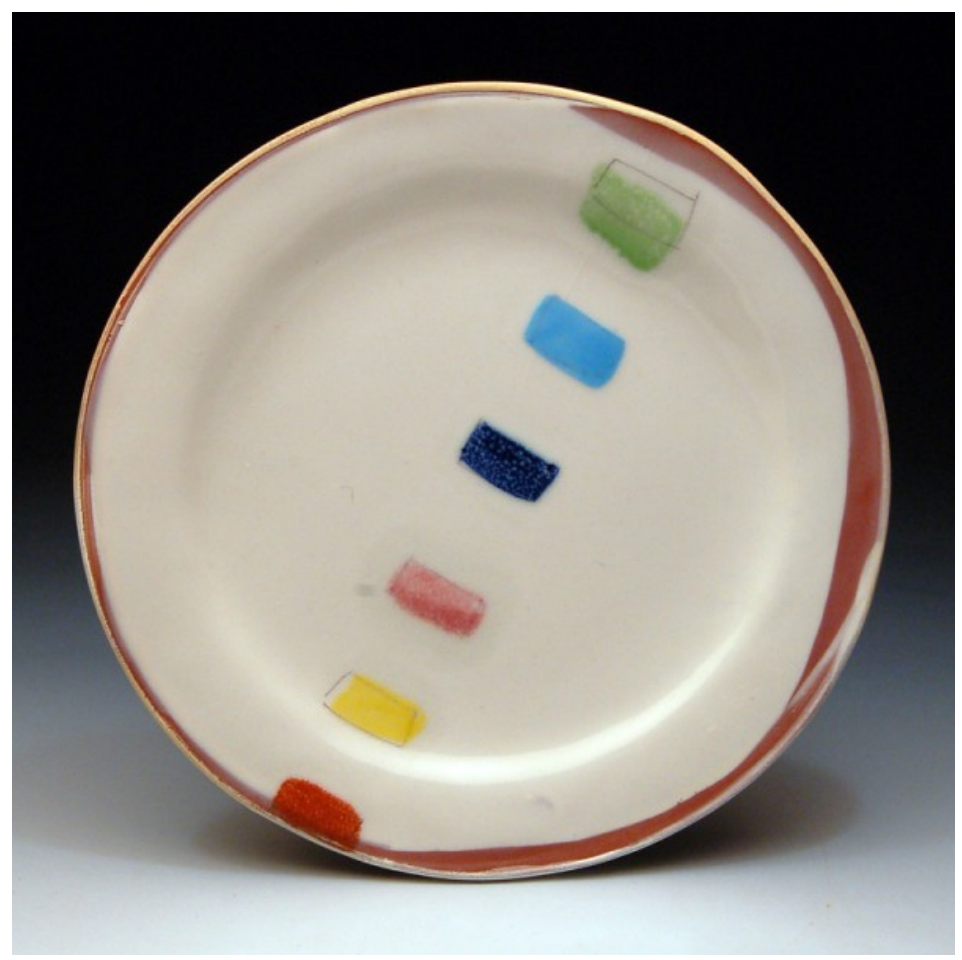

Figure 25: Brian R. Jones Plate

Earthenware 2011

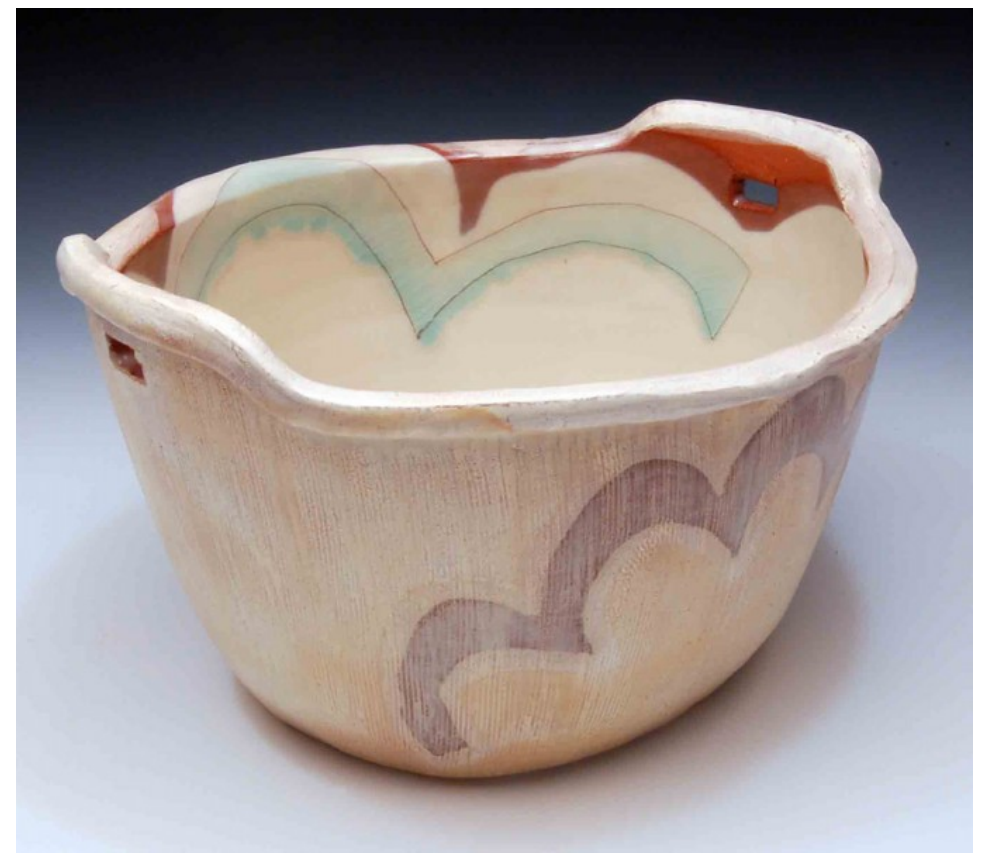

Figure 26: Brain R. Jones High Bowl Earthenware 2012 


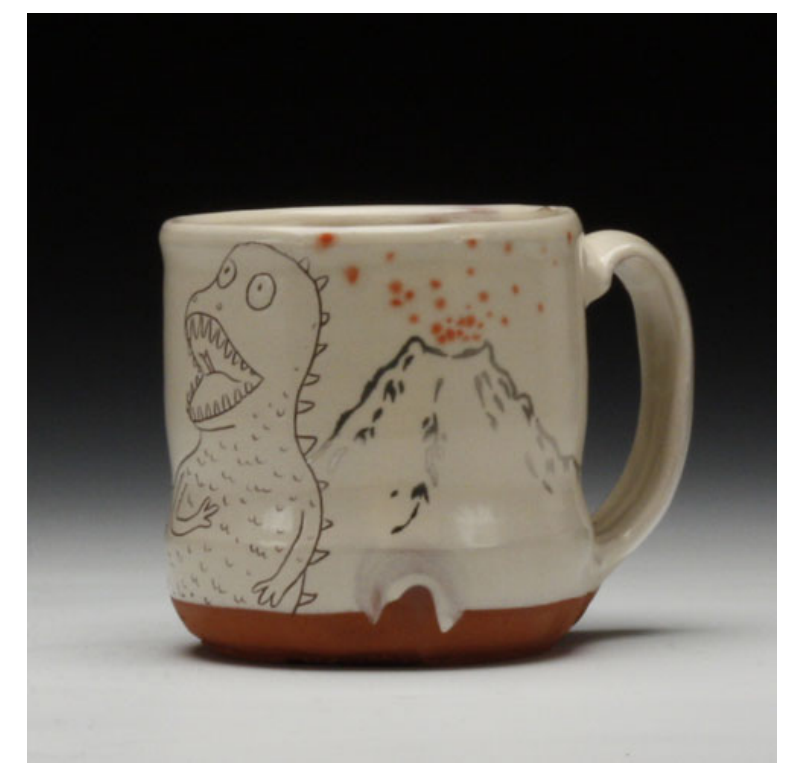

Figure 27: Ayumi Horie Mug

Earthenware 2006

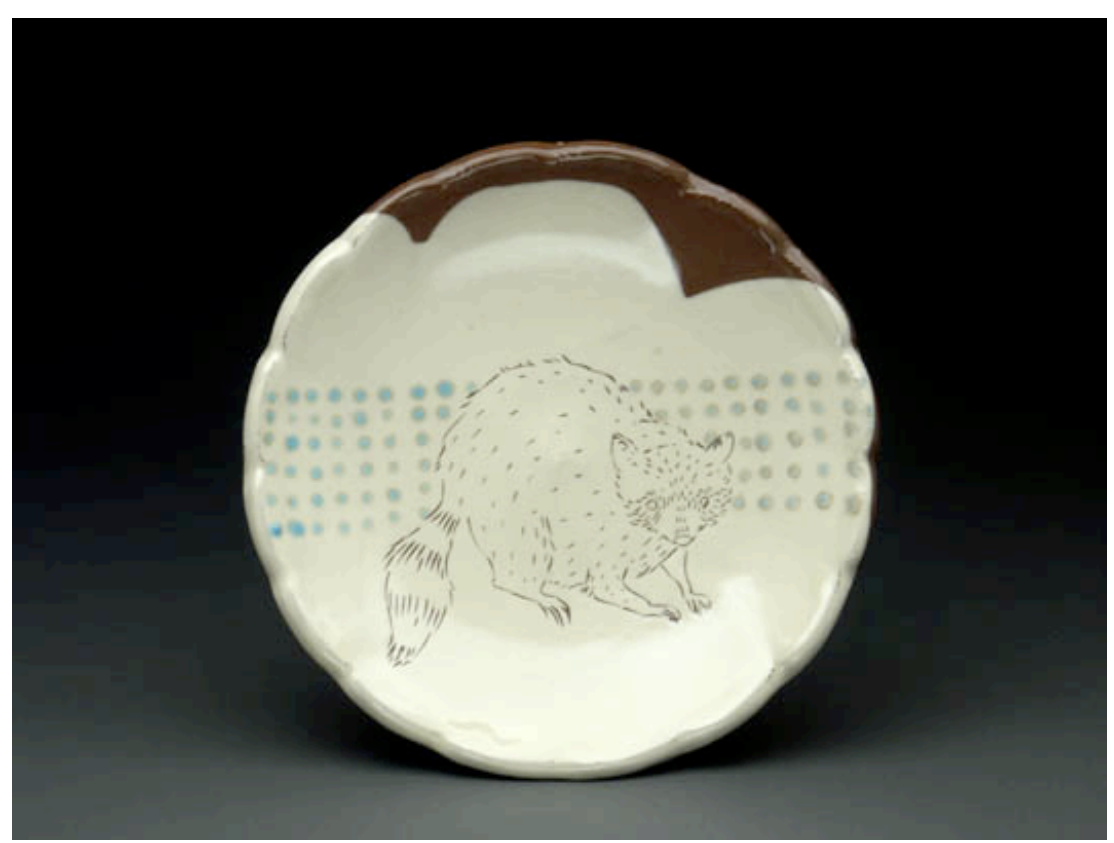

Figure 28: Ayumi Horie Raccoon Plate Earthenware 2010 


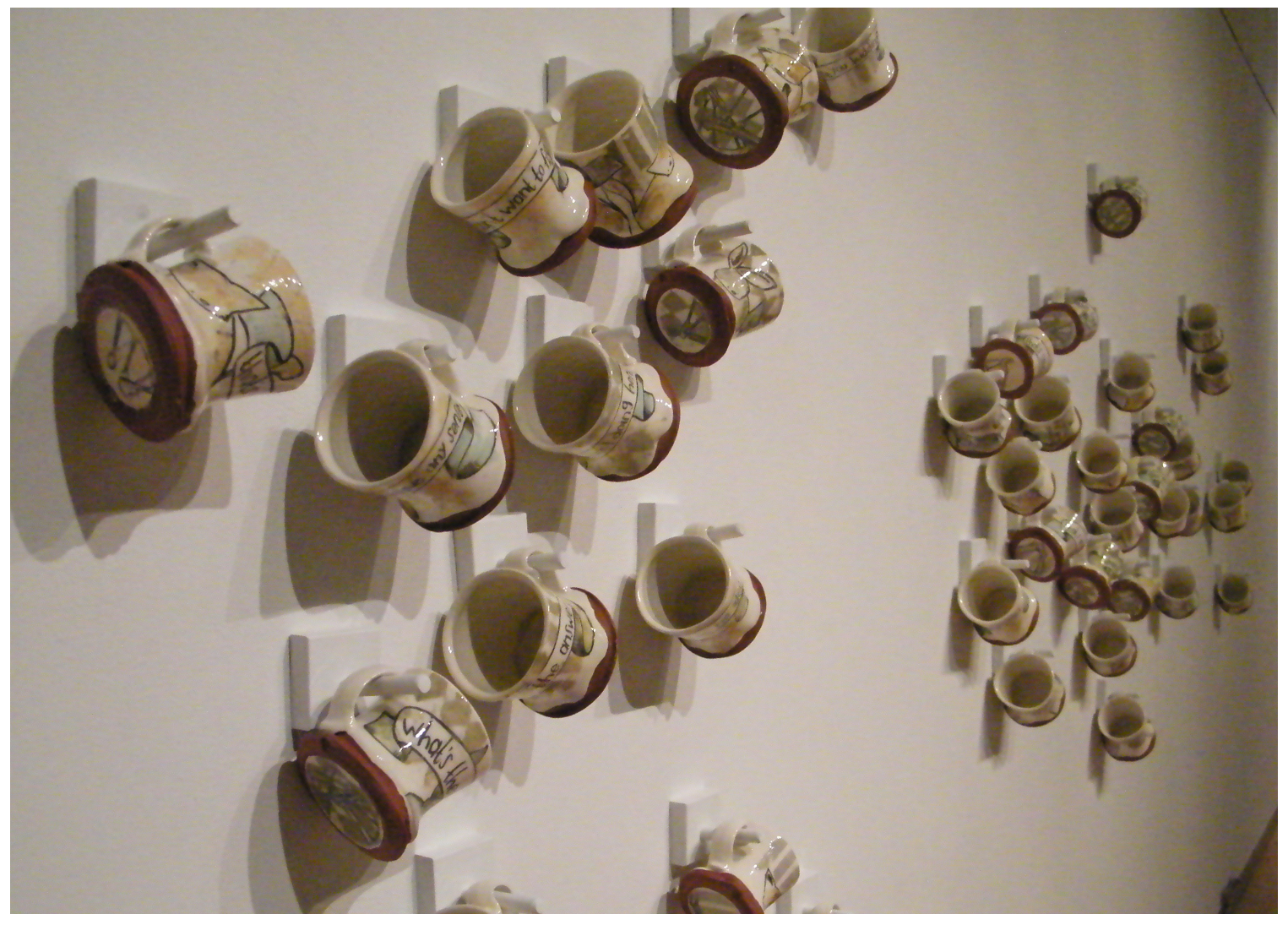

Figure 29: This Will Get Me Though the Day Mug Installation

Earthenware 2013 


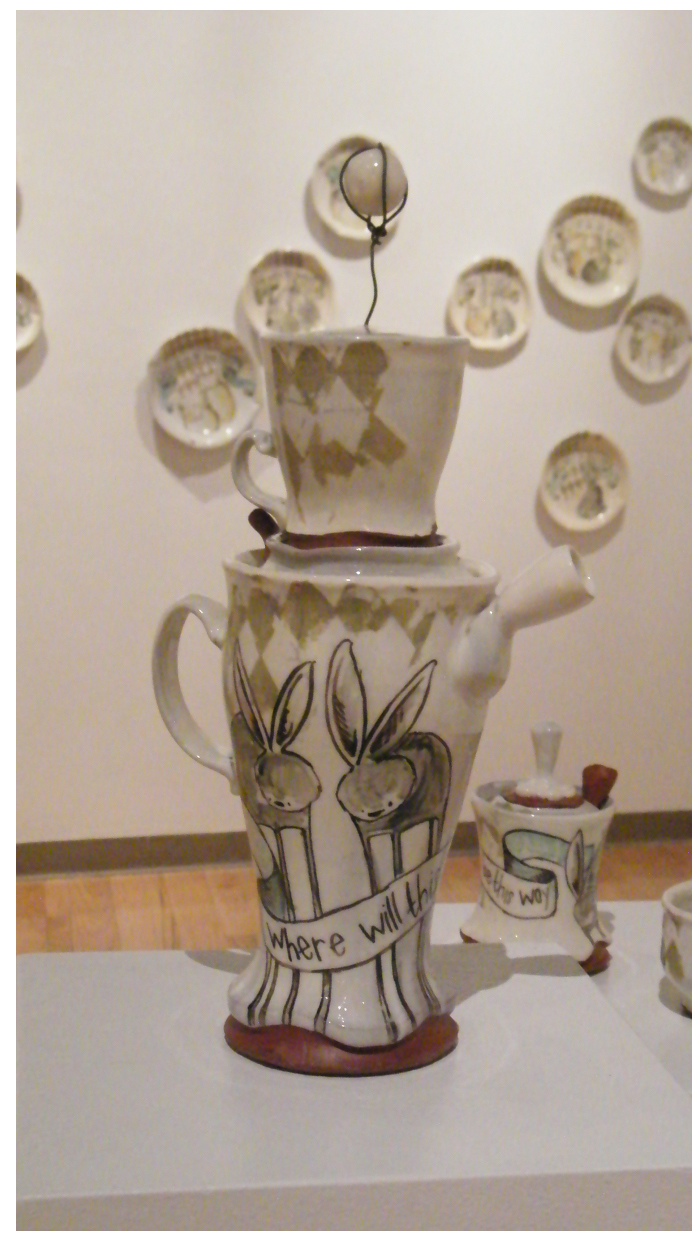

Figure 30: Moring Maker with Informational Receiving Antenna

Coffee Maker Earthenware 2013

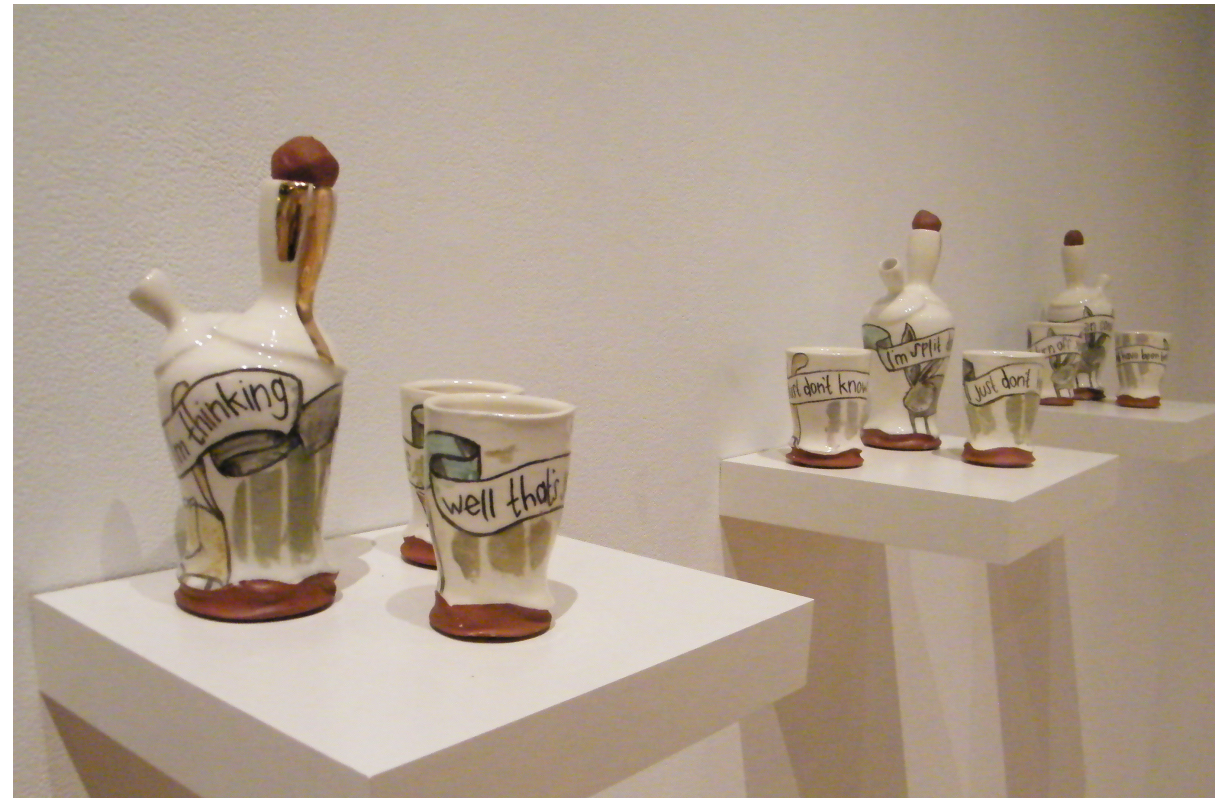

Figure 31: They Say Practice Makes Perfect

Bottles and Tiny Cups Earthenware 2013 

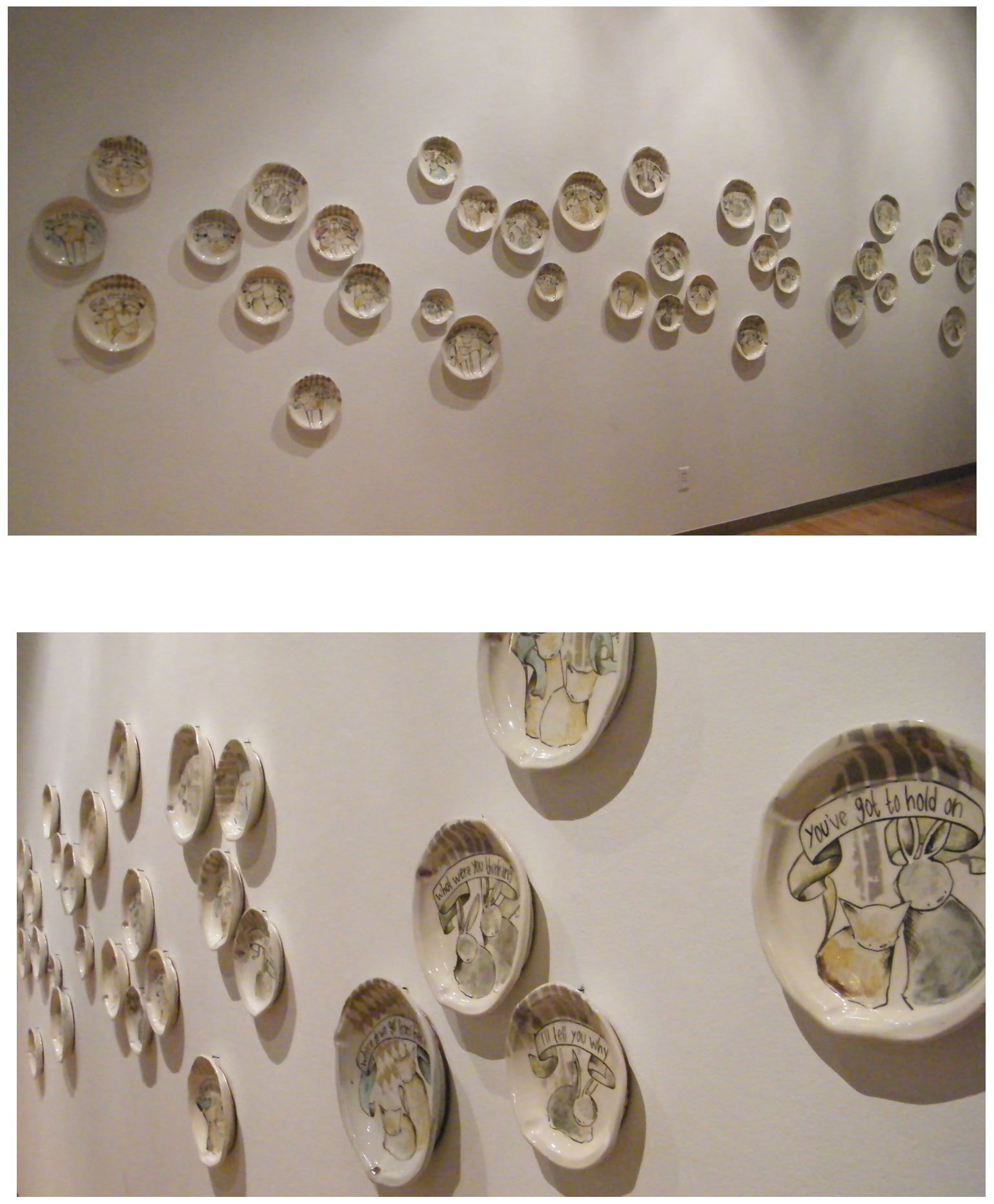

Figure 32: Collective Joy for the Masses

Plate Installation

Earthenware

2013 

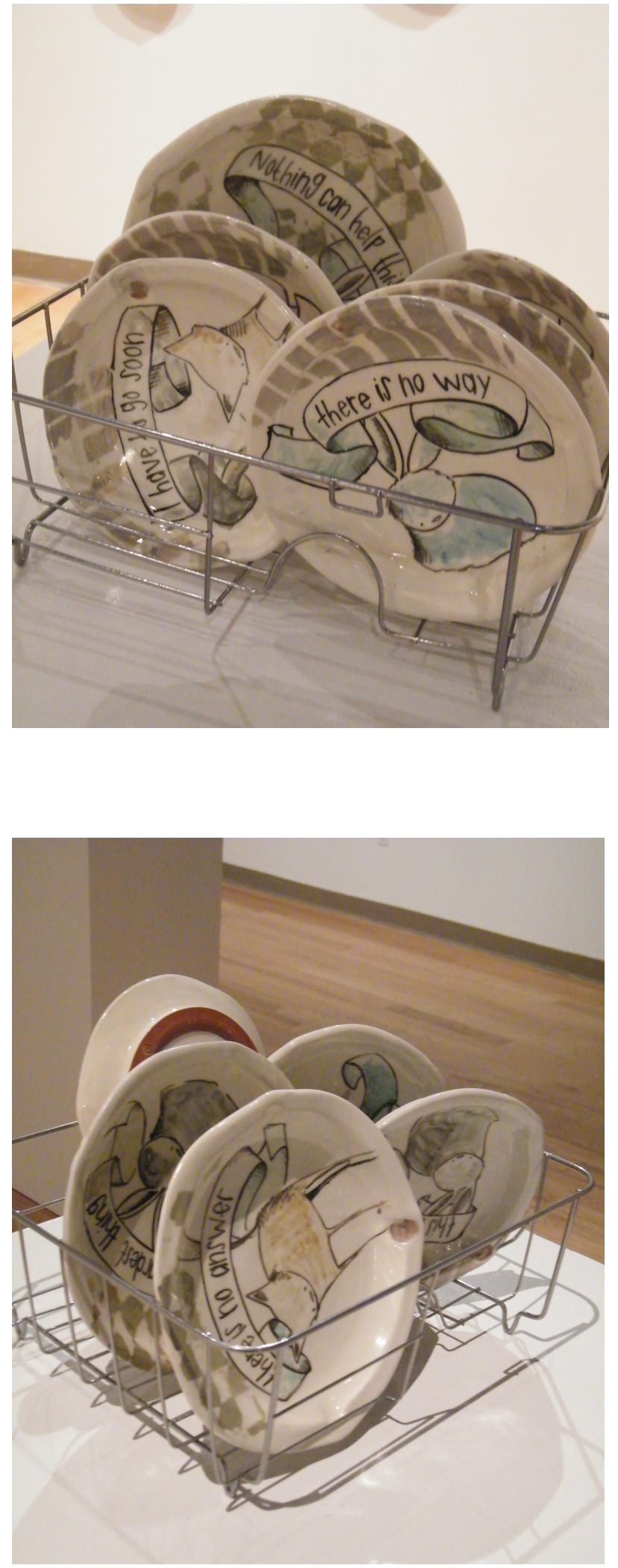

Figure 33: Sometimes the Answers are Hard to Find

Plates and Dish Rack

Earthenware

2013
Figure 34: A Little Scrubbing Might Solve the Problem

Plates and Dish Rack

Earthenware

2013 


\section{Bibliography}

Abram, David. The Spell of the Sensuous: Perception and Language in a MoreThan-Human World. New York: Pantheon Books, 1996.

Adorno, Theodor. "Functionalism Today." In The Craft Reader, edited by Glen Adamson, 395-403. New York: Berg Publishing, 2010.

Benson, W.A.S. "Elements of Handicraft and Design." In The Craft Reader, edited by Glen Adamson, 16-21. New York: Berg Publishing, 2010.

Clark, Garth. "How Envy Killed the Crafts." In The Craft Reader, edited by Glen Adamson, 445-456. New York: Berg Publishing, 2010.

Clark, Garth. Shards. China: Ocean Graphic Printing, 2003.

Collingwood, R.G. "Art and Craft." In The Principles of Art, 15-41. Oxford: Oxford University Press, 1972.

Crane, Walter. "The Importance of the Applied Arts and Their Relationship to Common Life." In The Theory of the Decorative Arts: An Anthology of European and American Writings, 1750-1940, edited by Isabelle Frank, 178-83. New Haven: Yale University Press, 2000.

Davidson, Margaret. Contemporary Drawing: Key Concepts and Techniques. New York: Watson-Guptill, 2011.

Dormer, Peter. The New Ceramics: Trends and Traditions. New York: Thames and Hudson LTD., 1994.

Foster, John. New Masters of Poster Design: Poster Design for the Next Century. Minneapolis: Rockport Publishers, 2008.

Gershkin, Paul. The Art of Modern Rock: The Poster Explosion. San Francisco: Chronicle Books, 2004.

Harris, Daniel. Cute, Quaint, Hungry and Romantic, The Aesthetics of Consumerism. Da Capo Press, 2000.

Heidegger, Martin. "The Origin of the Work of Art." In Poetry, Language, Thought, translated by Albert Hofstadter, 145-61. New York: Harper \& Row, 1971. 
Heidegger, Martin. "The Thing." In Poetry, Language, Thought, translated by Albert Hofstadter, 145-61. New York: Harper \& Row, 1971.

Hickey, Dave. The Invisible Dragon: Four Essays on Beauty. Los Angeles: Art Issues Press, 1993.

Koplos, Janet. "What Is This Thing Called Craft?" American Ceramics II, no. I (1993): 12-13.

Lane, Peter. Ceramic Form: Design and Decoration. New York: Rizzoli International, 1994.

Leach, Bernard. A Potter's Book. Trans Atlantic Arts, 1967.

Mathieu, Paul. The Art of the Future: 14 Essays of Ceramics. www.paulmathieu.ca/

Morris, Robert. "Some Notes of the Phenomenology of Making: The Search for the Motivated." In The Craft Reader, edited by Glen Adamson, 540-547. New York: Berg Publishing, 2010.

Morris, William. "The Arts and Crafts Today." In The Theory of the Decorative Arts: An Anthology of European and American Writings, 1750-1940, edited by Isabelle Frank, 61-70. New Haven: Yale University Press, 2000.

Morris, William. "The Revival of Handicraft." In The Craft Reader, edited by Glen Adamson, 146-155. New York: Berg Publishing, 2010.

Marcoci, Roxana. Comic Abstraction: Image-Breaking, Image Making. New York: The Museum of Modern Art, 2007.

Nakashima, George. "The Soul of a Tree." In The Craft Reader, edited by Glen Adamson, 219-225. New York: Berg Publishing, 2010.

Ostermann, Mattias. The Ceramics Surface. Philadelphia: University of Pennsylvania Press, 2002.

Rawson, Philip. Ceramics. University of Pennsylvania Press, 1997

Risatti, Howard. A Theory of Craft: Function and Aesthetic Expression. Chapel Hill: University of North Carolina Press, 2007.

Wolk, Douglas. Reading Comics: How Graphic Novels Work and What They Mean. Cambridge: Da Capo Press, 200 


\section{Erica E. Passage}

address: 7281 W Lake Drive, Fremont MI 49412

phone: 2312459966

email: ericapassage@gmail.com

Curriculum Vitae

Education

2013: M.F.A. Ceramics, West Virginia University, Morgantown, WV

2010: Study Abroad in China, West Virgina University, Morgantown, WV and Jingdezhen Ceramics Institute, Jingdezhen, China

2008: Penland School of Crafts, Penland, NC

2007: B.F.A. Ceramics, Central Michigan University, Mt. Pleasant, MI

2007: B.S. in K-12 Art Education, Central Michigan University, Mt. Pleasant, MI

2006: Study Abroad in China, West Virginia University, Morgantown, WV

Solo and Group Exhibitions

2013: A Series of Small Acts, Black Bear Evansdaele, Morgantown WV

2013: Confluence: West Virgina University Graduate Student

Exhibition, Artist Image Resource, Pittsburgh PA

2013: The Rational for Ridiculous: Master of Fine Arts Thesis

Exhibition, Laura Mesaros Gallery, Morgantown WV

2012: Sweet Treats Solo Exhibition, Nantucket Island School for

Design and the Arts, Nantucket MA

2012: Faculity and Staff Exhibition, Nantucket Island School for

Design and the Arts, Nantucket MA

2012: Home Grown: West Virgina University Graduate Exhibition, Artist Image Resource, Pittsburgh PA

2012: Florida show

2011: Shared Journey's II Ceramics Exhibition, Zen Clay, Morgantown WV

2011: Migratory Patterns Ceramic Exhibition, Nantucket Island School of Design and Art, Silo Gallery, Nantucket, MA

2011: Facutily and Staff Exhibition, Nantucket Island School of

Design and Art, Silo Gallery, Nantucket, MA 
2011: Ego/ Anti-Ego: West Virgina University Graduate Student Exhibition, Laura Mesaros Gallery, Morgantown WV.

2011: West Virginia Univeristy Ceramics Exhibition, Zen Clay, Morgantown, WV

2010: Bridging the Gap Ceramics Exhibition, Gallery 2, Jingdezhen, China

2010: Interlochen Staff and Facility Exhibition, Interlochen Center for the Arts, Interlochen MI

2009: Interlochen Staff and Facility Exhibition, Interlochen Center for the Arts, Interlochen MI

2009: Sketchbook Traveling Exhibition, Art House Co-Op, Atlanta, GA

2009: "Reworks" a Recycled Art Show, Hastings College of Art, Hastings, NE

2009: Prints and Pots Solo Exhibition, Delta College Galleria, Midland, Ml

2008: 6x6 Invitational, Kaya Gallery and Coffeehouse, Mt Pleasant MI

Other Awards, Grants \& Recognitions

2013: Graduate Teaching Assistantship: Ceramics Department, West Virgina University, Morgantown, WV

2012: Graduate Teaching Assistantship: Foundations Department, West Virgina University, Morgantown WV

2012: Graduate Teaching Assistantship: Ceramics Department, West Virgina University, Morgantown, WV

2011: Graduate assistantship, West Virginia University, Morgantown, WV

Teaching Experience

2013: Ceramics Instructor of Record, West Virgina University, Morgantown, WV

2012: Drawing Instructor of Record, West Virgina University, Morgantown, WV

2012: Ceramics Instructor, Nantucket Island School of Design and Art, Nantucket, MA

2012: Drawing Instructor of Record, West Virgina University, Morgantown WV

2011: Ceramics Instructor of Record, West Virgina University, Morgantown WV

2011: Ceramics Instructor, Nantucket Island School of Design and Art, Nantucket, MA

2010: Ceramics and Book Arts Instructor, Interlochen Center for the Arts, Interlochen, MI 
2010: Spring Ceramics Instructor, Newaygo County Council for the Arts, Arts Place, Adult Wheel Throwing and Kids at the Wheel Throwing Classes, Fremont, MI

2009: Fall Ceramics Instructor, Newaygo County Council for the Arts, Arts Place, Adult Wheel Throwing and Kids at the Wheel Throwing Classes, Fremont, MI

2009: Book Arts Instructor, Interlochen Center for the Arts Summer Arts Camp, Interlochen, Ml

2009: Spring Ceramics Instructor, Newaygo County Council for the Arts, Arts Place, Adult Wheel Throwing and Kids at the Wheel Throwing Classes, Fremont, MI

Other Art Experiences

2012-2013: President of Clay Club, West Virgina University, Morgantown WV

2011: Ceramics Intern, Nantucket Island School for Design and Art, Nantucket MA

2009: Kiln Technician, Interlochen Center for the Arts Summer Arts Camp, Interlochen, MI

2009: Visiting Artist, Wheel Throwing and Pottery Demonstrations, Fremont Middle School, Fremont, Ml

2009: Visiting Artist, Wheel Throwing and Pottery Demonstrations, Interlochen Center for the Arts, Interlochen, MI

2009: Raku Rodeo, Interlochen Center for the Arts, Interlochen MI

2008: Empty Bowls Assistant, Interlochen Center for the Arts, Interlochen $\mathrm{Ml}$

2008: Work Study, Penland School of Crafts, Penland NC

2008: Artist Assistant, Interlochen Center for the Arts Summer Arts Camp, Interlochen, MI

2008: Kiln Technician, Interlochen Center for the Arts Summer Arts Camp, Interlochen, MI

2008: Raku Rodeo Assistant, Interlochen Center for the Arts, Interlochen MI

2008: Throwing Demonstration, Fremont Middle School, Fremont, MI

Professional Organizations

2004-Present: National Council for the Education of Ceramics

Art, NCECA, Member

2007-2010: Southern Graphics Council, SGC, Member 